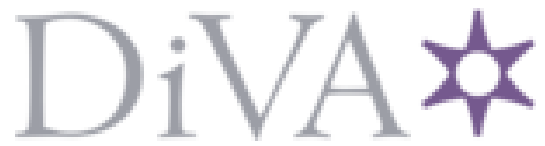

http://www.diva-portal.org

Preprint

This is the submitted version of a paper published in Political Geography.

Citation for the original published paper (version of record):

Döring, S. (2020)

Come rain, or come wells: How access to groundwater affects communal violence Political Geography, 76: 102073

https://doi.org/10.1016/j.polgeo.2019.102073

Access to the published version may require subscription.

N.B. When citing this work, cite the original published paper.

Permanent link to this version:

http://urn.kb.se/resolve?urn=urn:nbn:se:uu:diva-404362 
Please note that this the final draft prior to submission. Please always cite the final version:

Stefan Döring (2020). Come rain, or come wells: How access to groundwater affects communal violence. Political Geography, Volume 76, 102073. ISSN 0962-6298. DOI 10.1016/j.polgeo.2019.102073 


\title{
DRAFT - Come Rain, or Come Wells: How Access to Groundwater Affects Communal Violence *
}

\author{
Stefan Döring ${ }^{\dagger}$ \\ Research School for International Water Cooperation \\ Department of Peace and Conflict Research, Uppsala University
}

\begin{abstract}
This paper empirically analyzes the relationship between groundwater scarcity and incidences of communal violence. Case studies suggest that appropriating water is more likely when resource scarcities are not effectively mitigated and where property rights are disputed. Yet, covering water more broadly remains piecemeal in quantitative research on communal conflict. While water scarcity features in large-N literature on climate variability and non-state conflicts, such studies rely heavily on rainfall data which covers only one aspect of the hydrological cycle. Employing precipitation data alone neglects the use of groundwater, an important factor for drought resilience and the source for $50 \%$ of global drinking water. While rainfall remains key for agriculture, pastoralists and small-scale farmers in particular rely on groundwater as a buffer during dry periods. Thus, analyses on water scarcity and conflict ought to combine measures for groundwater, surface water, and precipitation. While controlling for other sources of water, the lack of groundwater access is hypothesized to increase incidences of violent communal conflict. The effect of groundwater on communal violence is also argued to vary with the presence of drought, low rainfall, in densely populated areas, and with state presence. These propositions are tested through large- $\mathrm{N}$ analyses using previously not utilized data on water availability with incidence data on violent conflict for Africa and the Middle East (1990-2014). The results show that lacking access to groundwater is associated with a higher risk of communal violence. Further, the effect of groundwater access on communal violence is conditioned by precipitation levels as well as population density. The results also suggest that the effect of groundwater on violence is smaller in areas with higher state presence.
\end{abstract}

*Words: 9,498. Version as of August 2019

†Correspondence: stefan.doring@pcr.uu.se; Dep. of Peace and Conflict Research, Box 514, 75120 Uppsala, Sweden

Acknowledgments: The author is grateful for feedback from Håvard Hegre, Ashok Swain, Hanne Fjelde, and Nina von Uexkull. The feedback and data support by Korbinian Breinl was much appreciated. For their helpful comments on earlier versions, I also thank Karen Brounéus, Mihai Croicu, Charlotte Grech-Madin, Sophia Hatz, Kyungmee Kim, Magnus Öberg, Susanne Schaftenaar, Eric Skoog, Isak Svensson, David Randahl, Ida Rudolfsen, and Annkatrin Tritschoks. I owe Inge de Graaf for generously sharing her data. The suggestions by three anonymous reviewers as well as Associate Editor Stefano Costalli were also much appreciated. All remaining errors are the author's alone. Research for this article has been supported by the UNESCO Category II International Centre for Water Cooperation, Stockholm, Sweden.

Declarations of interest: none. 


\section{Introduction}

Water access in Africa and the Middle East is distributed unequally, within regions and sub-regions, but also within countries. Rain-fed agriculture, for instance, can face severe problems as precipitation can be unpredictable in regard to quantity and timing. As a result, water management policies have advocated for irrigation schemes. The wetlands and plateaus in northern and central Nigeria are a good example: receiving relatively large amounts of annual rainfall, water shortages in northern Nigeria may occur because the rainy season starts later, but also because up to 50 percent of rainfall evaporates. Securing water throughout the year is crucial and a main reason behind an upsurge in the use of irrigation canals, dams, and boreholes. As droughts have become more common, the responses often mean even more diversion of water from wetlands or more frequent extraction of groundwater (UNEP, 2010). Such over-exploitation has severe consequences to the environment and to sustainable water access. This exemplifies the importance of providing access to a variety of water sources. Some communities are better equipped for droughts because of diversified available water resources, others are suffering. The same Nigerian regions have also witnessed communal clashes over grazing rights and access to water resources, for example during the recent dry seasons (Patience, 2016; Searcey, 2018). Communal conflicts, such as farmer-pastoralist disputes, have been recurring and even spilled over to other areas fueling tensions based on other group divisions (Higazi, 2016). Similar conflicts occur in other parts of Africa and elsewhere. With a focus on groundwater access, this article investigates the relationship between water scarcity and communal violence. Because water scarcity is determined by the availability of several water sources, I also account for rainfall, drought, and major rivers in my analysis.

Communal violence has been studied from different perspectives. On one hand, geography literature has approached such disputes predominantly through rich case studies. Political science on the other hand has studied such violence rather quantitatively and in regard to climate change. Focusing on the effect of climate-related drought through agriculture, previous research (for example: Böhmelt et al., 2014; Wischnath \& Buhaug, 2014; von Uexkull, Croicu, Fjelde, \& Buhaug, 2016) has predominantly relied on precipitation data to gauge the effects of water scarcity. Yet, when establishing the societal consequences of water scarcity, it is key to also consider more stable sources of water access. In addition, especially large- $\mathrm{N}$ research on water resources and armed conflict has almost entirely neglected groundwater. This is surprising given the different ways to capture water. Firstly, common sense suggests that the distance to surface water should be an important factor for water access, but this is not universally valid. While human settlements are indeed on average in the vicinity to water bodies, research shows that particularly in Africa, even considerably dense settlements can be far away from rivers (Ceola, Laio, \& Montanari, 2015). Thus, for people living further away from surface water, having access to rainfall or groundwater is crucial. Accounting for rainfall remains essential because most farming in Africa is rain-fed and because of the importance of seasonal rain for pastoralism. Seminal work from ecology and human geography has advanced our understanding of farmer-herder disputes 
through case studies (e.g. Bassett, 1988; McCabe, 2004; Turner, Ayantunde, Patterson, \& Patterson, 2012; Benjaminsen \& Lund, 2002; Benjaminsen, Maganga, \& Abdallah, 2009; Lund, 2008). In such research, water is often a key component in competition over land. Bridging these different strands of literature, I argue that access to groundwater is key for our understanding of communal violence regarding both land disputes and links to climate change.

This article analyzes whether limited groundwater access is associated with violent communal disputes. Communal violence is defined as fatal disputes between non-state groups organized along communal identities. When analyzing the links between conflict and water scarcity, it is necessary to take into account different water sources that can mitigate climate related dry spells. Thus all regression models include measures for groundwater, precipitation, drought, and the presence of major rivers. Furthermore, this article contributes in several ways to a slowly rising tide in the field. Theoretically, the work explains how communities can mitigate the consequences of water scarcity. Because it is available at a more steady rate, groundwater represents a vital buffer in times of drought. I argue that more difficult access to groundwater makes incidences of communal violence more likely, and that such effects are also more pronounced in times when other water resources are lacking. In this article I find lacking groundwater access to increase the risk of communal violence. The results of this study contribute empirically by providing a better picture on the type of water resources that can be associated with communal conflict. The link between access to groundwater and communal violence is conditioned by precipitation levels, population density, and state presence. Expanding the geographic coverage of previous studies on Sub-Saharan Africa, this work adds areas in Northern Africa and the Middle East to the analysis.

\section{Previous Literature}

Policy-makers have repeatedly emphasized the role of water diplomacy to tackle conflicts over water (Susskind, Ali, \& Hamid, 2014). This political focus builds on narratives linking violent conflict and insufficient water supplies from media reports and general policy debates. For several years, the World Economic Forum, for instance, has named "water [supply]" a top priority danger in their annual Global Risk reports (WEF, 2017). Yet, robust evidence for a direct relationship between water shortage and violent conflict is hard to come by. While some literature has theorized and pointed towards possible "water conflicts" (Falkenmark, 1990; Homer-Dixon, 1994; Swain, 1993), there is no cross-case, empirical evidence for "water wars" between countries (Brochmann \& Gleditsch, 2012; Bernauer \& Böhmelt, 2014; Grech-Madin, Döring, Kim, \& Swain, 2018). More recent cross-case analyses therefore shifted to investigating the conditional effects of meteorological drought on conflict (Detges, 2016; von Uexkull et al., 2016; Fjelde \& von Uexkull, 2012). Yet with their focus on drought or rainfall, much of the established literature only covers one aspect of available water resources.

Rainfall is predominantly used for agriculture, whereas groundwater serves several additional pur- 
poses. Groundwater access is key for small-scale family farms which constitute almost 70 percent of Africa's agricultural land (Graeub et al., 2015). Especially rural communities heavily rely on groundwater for their households. Groundwater is essential for livestock or livestock fodder, and about three quarters of Africa's population use groundwater as their major source of drinking water (Edmunds, 2012; Foster, Tuinhof, \& Steenbergen, 2012; UNEP, 2010; World Bank, 2018). Furthermore, groundwater irrigation has become more common both at the commercial and the subsistence farming levels during the last decades. Almost all countries in Africa and the Middle East have been equipped with groundwater irrigation (Siebert et al., 2010). While cities mostly tap into deep groundwater aquifers or surface water ${ }^{1}$, shallow groundwater is essential to small and mid-sized towns as well as the outskirts of urban centers (Edmunds, 2012; Foster et al., 2012; UNEP, 2010). Moreover, groundwater is often the sole water supplier for refugee camps, where shortages and contamination can have severe health consequences (Fiddian-Qasmiyeh et al., 2011; Tuinhof et al., 2011). In sum, it is crucial to consider groundwater access in addition to other water sources.

Access to water is central for farmer-herder relations in both Africa and the Middle East. Work within Geography and Ecology has provided important insights to the role of water scarcity to communal groups. Mujeeb and John (1992) and Bogale and Korf (2007) for instance show how different well types are utilized for livestock farmers in Somalia and Ethiopia, respectively. However, insights from this field also connect directly to conflict research by dealing with resource disputes; in particular, linking water and conflict relates to competition over land use (Benjaminsen \& Lund, 2002). Across Africa, questions of land control can be opaque. Even land tied to a small village can comprise varying ownership types, which can create serious friction between land users (Turner \& Moumouni, 2018; Bogale, Taeb, \& Endo, 2006). Yet, most disputes between farmers and herders remain relatively peaceful. In fact, informal conflict resolution is a preferred tool for many groups and such institutions can meaningfully prevent violence from escalating (Turner et al., 2012; Bogale and Korf, 2007; cf. Ostrom, 1990). Nonetheless, disputes over land tenure can turn violent. For example biased local politics have been shown to negatively influence informal conflict resolution mechanisms (Boone, 2014; Lund, 2008; Brosché, 2014; Elfversson, 2019). Benjaminsen et al. (2009) show how pastoralists in Tanzania bribed police which eventually turned farmers towards financing their own militia. Dynamics between shifting local politics and different livelihoods are also visible in farmer-herder conflicts in Burkina Faso (Hagberg, 2004), Chad (Jánszky \& Jungstand, 2013), Ethiopia (Bogale \& Korf, 2007), Ivory Coast (Bassett, 1988), Kenya (Bollig, 1993; Fratkin, 1994; McCabe, 2004; Greiner, 2013), or Mali (Benjaminsen \&

\footnotetext{
${ }^{1}$ Particularly for urban areas it is important to take into account water quality. In Africa's arid and semi areas, the level of salinity can significantly hamper the use of water for households or irrigation (Edmunds, 2012). This is not necessarily a problem for small-scale wells that often use shallow reservoirs. As a rule of thumb, deeper groundwater aquifers have a higher the risk of salinity. Furthermore, hazards through high arsenic and manganese content are being recognized more frequently, and adjusting to such problems is less burdensome than using micro-biologically polluted surface waters (Tuinhof, Foster, van Steenbergen, Talbi, \& Wishart, 2011). Another problem is the excessive use of groundwater which has contributed to falling water tables and alongshore intrusion of sea water (Swain, 2004; Post, Eichholz, \& Brentführer, 2018).
} 
$\mathrm{Ba}$, 2009). Such studies provide detailed insights into the motivations of the use of violence by different non-state groups. In addition, cattle raiding represents the display of power and pride to some pastoralist groups; this may even explicitly include the killing of other herders or farmers (see for example Bollig, 1993; McCabe, 2004; Greiner, 2013). Nonetheless, the majority of communal violence emerges through land disputes that are rooted in inadequate state control and unclear land-rights systems.

Both qualitative and quantitative conflict research on communal groups has predominantly covered Africa. Conflict between non-state groups can be broadly distinguished in disputes over territory, authority, and lootable resources (von Uexkull \& Pettersson, 2018). Focusing on communal conflict over land in West Africa, Eck (2014) finds that regions with vying jurisdictions are significantly more conflict prone. On the other hand, states are more likely to intervene if communal conflicts are about the control of land and if the government is ethnically tied to the disputed areas (Elfversson, 2015). This also relates to government biases which can create unclear boundaries and hamper the ability to settle conflict (Elfversson, 2019), which can ultimately drive conflict escalation (Brosché, 2014). Whereas shocks in food prices have not been shown to be linked to communal conflict (Buhaug, Benjaminsen, Sjaastad, \& Theisen, 2015), non-state conflict is more likely in the wake of regime changes (Kreutz \& Eck, 2011), or with high levels of inequality among individuals or ethnic groups (Fjelde \& Østby, 2014).

Studying the effects of droughts (or rainfall patterns) on communal conflict has been featured more frequently in the course of the last years. This development has been propelled by access to enhanced data, which has allowed research to move to sub-national levels of analysis (Eck, 2012; Fjelde \& Østby, 2014). Yet, water as such is mostly playing a minor role as a range of studies focus on different aspects of climate variability or the consequences of climate change. The majority of such quantitative studies have relied on rainfall data. One notable exception is the study on pastoralist violence by Detges (2014) which finds fighting more likely close to well sites in Northern Kenya. Raleigh and Kniveton (2012) come to quite counter-intuitive results while looking at rainfall variation and conflict in Ethiopia, Kenya, and Uganda: they find communal conflict to be more likely in anomalously wet areas. Several studies have found rather inconclusive results when combining rainfall variability and conflict in parts of East Africa (Meier, Bond, \& Bond, 2007; Ide et al., 2014; O'Loughlin et al., 2012) or Sub-Saharan Africa (O'Loughlin, Linke, \& Witmer, 2014). Using a dataset on 46 African countries, Hendrix and Salehyan (2012) find extreme precipitation, high and low, to be correlated with violent events, among various other kinds of political conflict. Similarly, research by Fjelde and von Uexkull (2012) suggests that unfavorable deviations from precipitation patterns increase the risk of communal conflict. A more detailed picture is provided by Nordkvelle, Rustad, and Salmivalli (2017) who are comparing periodic climate impacts; they find short-term dry periods as well as unusually long wet periods to affect communal violence. Yet, discussing conflicts over water specifically, Böhmelt et al. (2014) find no evidence that short-term changes in rainfall and temperature are eminent explanatory factors for such disputes. There seems to be more agreement that the effect of water scarcity on communal violence is conditional 
on other factors. For example, violence following drought is more likely where a substantial share of the population lacks access to water infrastructure (Detges, 2016; Landis, Rezaeedaryakenari, Zhang, Thies, \& Maciejewski, 2017) or where groups are politically marginalized (Fjelde \& von Uexkull, 2012; Detges, 2017).

Overall, the existing literature leaves behind several shortcomings. While there are many in-depth case studies on farmer-herder conflicts, there are very few large-N studies on communal violence and water scarcity beyond meteorological drought. Moreover, to the author's knowledge, there is no large$\mathrm{N}$ study on armed conflict that incorporates groundwater access. It is also striking that a large amount of studies analyze solely East Africa, or Sub-Saharan Africa. A reason for this is surely the increased number of communal conflicts in this region. However, well-specified models should be able to also cover other geographic areas, where despite being rare, communal violence is not absent. Another gap emerges when looking at the employed data sources. Though some recent studies have moved to the sub-national level, no study has used geo-spatial data on a combination of groundwater, rivers, and precipitation together with information on violent communal conflict. To study possible links between water scarcity and violent conflict, our analysis ought to move away from solely relying on precipitation and drought measures. Instead, such research needs to take into account a broader range of factors that influence access to water. This article takes a significant step in this direction by providing an analysis of groundwater access and incidences of communal violence in Africa and the Middle East.

\section{How Scarcity Leads to Violence}

As argued above, other water resources, mainly rain and surface water, are crucial for communities in the study area. Thus, theories about the effects of water scarcity are proposed with explicit reference to the availability of different sources of water. The main argument rests on the fact that groundwater is more readily available year-round and sometimes far away from streams and rivers. Groundwater therefore can provide a much needed buffer to communities that suffer from water shortages.

This articles analyzes how variation in groundwater access affects incidences of communal conflicts. Such violence is understood as disputes between non-state groups that are informally mobilized along a common identification. Group affiliation often rests on religious, ethnic, or language identifiers which in turn might overlap with distinct livelihoods, e.g. visible through farmer-herder disputes (Brosché \& Elfversson, 2012; Turner et al., 2012). Water scarcity, or more generally, the access to water can be central components of such disputes. In this article water scarcity refers to the physical shortage of water resources for an inhabited geographic area. Such physical shortage can also be explained by different incompatibilities involved with water sharing. This includes three main domains, namely quantity, quality, and control of water (Swain, 2012). Though conflict over water can occur involving one domain or a combination of them, the causes for water scarcity or water stress can be manifold. Having only insufficient water resources can be due to climatic processes, for example through periodic drought 
and rainfall variation. Moreover, scarcities can also be due to financial constraints, for example with increased costs for labor or fuel. In Africa [and Asia], demographic trends are associated with frequent water shortages. Such development is explained by fluctuating transportation and infrastructure costs, poor urban planning, or the higher competition over water between the industrial, agricultural, and municipal sectors (UNEP, 2010). Short supply of fresh water often goes along with pollution and the over-exploitation of ground- or surface water. Such processes can lead to feedback loops whereby a local scarcity, e.g. due to over-exploitation, leads to more pollution or an increased overuse.

The exact pathways between water scarcity and violence are still not fully understood. Without more comprehensive knowledge on the exact causal mechanisms, the proposed links are non-deterministic, they thereby do not necessarily reflect the sole causes for violent behavior. Thus, the proposed theory linking resource scarcity and violence centers on probabilistic argumentation (Cederman, Gleditsch, \& Buhaug, 2013). A second caveat is that not all causal mechanisms can be tested for large areas due to restrictions in the data. Yet, water scarcity is a key factor that can provide crucial insights because the related available measures enable comparisons spatially and over longer time periods. Scarcityinduced suffering aggravates already existing incompatibilities and thereby enables violent behavior. While communal violence is the visible outcome on a group level, the underlying processes cannot be conceptualized through one level of analysis, instead they oscillate between the national (or federal), community, and individual levels. Linking water scarcity to communal violence, these mechanisms incorporate weakened state presence, fewer adaption opportunities, and local migration.

On the group or individual level, water scarcity emerges through different social and cultural processes. At its core, water scarcity implies that the attainable water sources cannot cover what is actually required for average use. This presupposes a persisting discrepancy between existing supply and expressed demand (Steduto, Faurès, Hoogeveen, Winpenny, \& Burke, 2012; WWAP, 2015). The notion of needs being perceived or expressed is important because scarcities are not merely about physical limitation, but also about subjective restraints evident through existing norms and practices (Homer-Dixon, 1994). The effect of a tangible shortage can lead to varying degrees of perceived shortages depending on a given group's socio-political practices. The same shortage in quality or quantity does not necessarily have the same effect everywhere. Marginally smaller amounts of water can threaten the yield of farmers in one area, while similar losses can have almost no impact to others. Thus, varying norms around water are linked to different purposes of water use. Everything else equal, communities that use groundwater only for sanitation and nutrition purposes might be less susceptible to shortages than communities who also use groundwater to irrigate their crops or provide water to their cattle. Thus, extreme water scarcity not only worsens the conditions for those engaged in agriculture, farming, or herding. Above all, severe water stress impairs living conditions and poses a serious threat to all forms of subsistence by diminishing access to nutrition and sanitation.

The causes of experienced water scarcity vary and it is clear that not all water scarce regions of the 
world witness violent communal conflicts. Municipal, federal, or other state administrations, along with their institutions, are important factors that can mitigate the problems relating to both water scarcity and communal disputes. When states can provide the protection of property-rights, the likelihood of communal violence should decrease (Butler \& Gates, 2012; Eck, 2014). The opposite applies where state presence is weak or where rules are ambiguous. For instance, seizing water access from other communities should be more conceivable in light of limited state enforcement. Furthermore, in areas with particularly low state presence (or even absence) some groups more easily display anger against other groups. Channeling violence towards other groups instead of the state can also be a consequence of the mere absence of authorities (Fjelde \& von Uexkull, 2012), or because such an endeavor bears considerable risks for smaller groups who often have already limited capabilities (Hendrix \& Salehyan, 2012; Raleigh, 2010). Moreover, the reach of the government is also infringed or legitimacy is lost when otherwise well-intended state actions fail to adequately curb the burden of deficient resources, deteriorating economies, and increased migration pressure. In Africa and the Middle East, state programs sometimes reach only a marginal amount of the respective country's population. Thus, water provision remains a communal issue and severe scarcities can increase the risk of appropriation and disputes.

In times of resource scarcity, some groups may receive limited help by the state simply due to their geographic remoteness, or due to political reasons — in both cases, negligence de-legitimizes the government and negatively affects compliance with the law. Governments can have different incentives to engage in local disputes, especially in more rural regions. A reason to engage might be due to kinship ties or simply because of the previous prevalence of disputes. On the the hand, even more formalized local agreements on land sharing are not always to the benefit of all. This applies especially when laws coexist with other regulations that differ depending on the level of jurisdiction. Legal plurality can for instance hamper existing informal conflict resolution or enable corrupt local politicians to make ownership rules more favorable to themselves (Benjaminsen \& Lund, 2002; Turner et al., 2012). In this way limited government presence also loosens existing regulation of land boundaries which allows farmers or other groups to expand their territory and enforce their own land sharing rules (Benjaminsen $\& \mathrm{Ba}, 2009)$. Such actions create further tensions and can legitimize forceful appropriation of land for those being discriminated against. Furthermore, biased local policies or security forces can also create impunity for those aligned with them.

It is important to consider that violence remains a last resort and the consequences of water scarcity more often are mitigated by informal or formal institutions. These can be shaped by a community and through state policies (Ostrom, 1990). Yet, the tools that help communities to adapt to scarcity are not unlimited, nor do they always provide enough remedy. An immediate reaction to shortage is rationing or shifting to less water-intense agriculture. Such adaptation processes have been argued to speak against theories linking water scarcity and conflict. Clearly, shortages can lead to accepting lower 
water quality and quantity, but such strategies cannot work infinitely. In fact, some communities in Africa or the Middle East have already lived with frequent water shortages for decades and the increasing resource demands ${ }^{2}$ do not necessarily increase adaptive capacities at the same rate. In addition, communal conflicts over resources are not new phenomena, settling communal disputes have cost lives in the past. For example in Nigeria or Kenya, conflicts over grazing rights or the diversion of streams are not new as such disputes have turned violent for more than a century (Boone, 2014; Papaioannou, 2016). This also suggests that some communities might have reached limits to adaption already. With continuing over-exploitation of groundwater and the recurrence of severe droughts, appropriating water through violent means represents a very feasible adaption strategy to some groups.

Another example of the finite character of adaptation is local migration. Migrating does not preclude that violence will still occur where scarcities are found. In fact, appropriating the remaining fertile land or water access might seem more conceivable when collective knowledge over traditional property rights is shifting due to flight. For instance, reports of land appropriation increased even after tens of thousands had left drought affected Nigerian provinces (Papaioannou, 2016). More importantly, moving to another place does not necessarily refer to long-distance migration (which also rather happens over longer time periods); instead, migration often occurs within smaller administrative boundaries, especially when intended as a temporal coping mechanism. Migration to nearby areas is always preferable if possible. In the wake of extreme scarcities, resettling to an improved surrounding is a tangible remedy which constitutes a short-term adaptation process (Koubi, Spilker, Schaffer, \& Bernauer, 2016). Such short-range mobility can be attractive to farmer households or herders who are facing water scarcities. For farmers, such relocation can simply mean finding seasonal employment in a neighboring village, whereas herders would relocate their grazing areas to more fertile land. Yet, temporary relocating can create disputes by changing existing societal structures through new economic interactions, via re-distribution of land, or by altering the political power balance between ethnic groups (Homer-Dixon, 1994, p. 20). These disputes can then also lead to the use of violence.

Un-addressed water scarcity or the resulting migration leads to suffering. In this way serious frictions can arise among communities as contention occurs via group affiliation. It is important to note that group identities are not only tied to religion, politics, or ethnicity; divisions can also rest upon other features, for example current landowners versus the more recently arrived migrants, or between sedentary and nomadic farming (Bassett, 1988; Brosché \& Elfversson, 2012). Thus, temporary or longterm migration creates group identities or substantiates existing differences. Attempting to cope with harsher conditions, people exposed to such scarcities might accept more burdensome means to obtain water, i.e., walking longer distances, or they adapt to lower water quantity and/or quality. However, such adaption processes can make communities even more vulnerable by potentially threatening living conditions and at the same time contribute to further distress. One strand of argumentation conceives

\footnotetext{
${ }^{2}$ Increased demands are due to higher living standards and population growth, among other things.
} 
violent appropriation as the only immediate way out of such types of suffering. More specifically, relative deprivation holds that people become violent as they perceive a grave mismatch between their expectations and their actual situation (Gurr, 1970). Hence, higher levels of discontent should convey a higher likelihood of violence. Another line of argument alludes to the lowered opportunity costs of associating oneself with individuals that use violence (Collier \& Hoeffler, 2004). Such costs are significantly lower when people have to face suffering and loss of income. Consequently, severe water scarcity can lead to situations where violence is used to resolve disputes over water allocation.

As grievances might occur only in those areas with unequal access to water, it is important to distinguish different sources for water. While piped or bottled water are available resources in most urbanized parts of the world, more rural areas often rely on a combination of rain, surface water, and groundwater. The latter serves as the predominant adaption tool against drought because it is vital for cattle or goat herding (de Graaf, Sutanudjaja, van Beek, \& Bierkens, 2015; Tuinhof et al., 2011). Making use of groundwater has been widespread for a long time, especially where access to water is possible with manual labor. Studies on East Africa (Butterworth, Sutton, \& Mekonta, 2013; Staro, 2014), Ghana (Grönwall, 2016), Mali (Lutz, Thomas, Pohl, Keita, \& McKay, 2008), and Nigeria (Nyong \& Kanaroglou, 1999), among others, show that although fresh water supply of small rural communities relies increasingly on modern hand-pumped wells, more traditional shallow hand-dug wells are still most prevalent across Africa.

This article argues that groundwater access is crucial when analyzing water scarcity and communal conflict. State presence, lowered adaption opportunities, and short-range migration are three key causal paths that explain how limited water access can increase the likelihood of communal violence. However, given the limitations for disaggregated data on migration and state capacity, it remains difficult to unpack and specifically operationalize these exact causal mechanisms for a large geographic area and over several years. A vital first step is thus to test the proposed theory by comparing the levels of groundwater access to incidence of communal fighting. More specifically, while accounting for the effect of other sources of water, limited access to groundwater should display an increased risk of violence because this type of water is available at a more permanent rate. While groundwater is mostly available year-round, the depth to the aquifer can change over years (but also within one year). Deeper groundwater tables require additional labor or equipment, which means that the access to water will be more scarce and limited the further the water table extends from the surface. Thus, I propose the following main hypothesis:

\section{$H(I):$ Areas with limited groundwater access are more likely to experience communal violence.}

Furthermore, water scarcity can be the result of different types of water shortages. Even in a country with abundant water resources like Malawi (rainfall, surface water, etc.), the majority of rural households rely on groundwater as their main source of water (Kanyerere, Nkhata, \& Mkandawire, 2009, p. 224). Be it rain or groundwater, relying on one water resource alone might not suffice in areas where 
both resources are relatively scarce. In short, groundwater access should matter more where other water sources are scarce. This is also explained by groundwater being an important buffer in periods of diminishing rainfall. Thus, the effect of one water resource on communal violence should be conditioned by the availability of other available sources of water. In particular, the effect of groundwater access on conflict should be conditioned by low rainfall or drought:

H(II): The effect of groundwater access on communal violence is larger in areas experiencing drought.

H(III): The effect of groundwater access on communal violence is larger in areas with lower rainfall.

In most parts of the world, population density is increasing. This is true for cities, but even for towns and larger villages. Especially in Sub-Saharan Africa, exploitation of groundwater has increased markedly in last 20 years. Restricting the amount of groundwater withdrawal has been a problem both in urban and rural settings. With a growing total amount of water users, the pressure on existing water resources increases at a higher rate because of greater demands on food production. In addition, more densely populated areas also create higher demand on sewage systems and other services. Similarly, disputes between farmers and herders increase where urban areas require higher agriculture outputs or where nearby farmland increasingly encroaches into pastures. In sum, this means that the effect of dwindling groundwater access should be more pronounced in more densely populated areas.

$H(I V)$ : The effect of groundwater access on communal violence is larger in areas with higher population density.

As argued above, the level of state presence affects both the management but also the provision of water. This should matter even more where groundwater is harder to extract. When resources are scarce, increased state presence mitigates the consequences for communities, for example by building deeper wells or better infrastructure for the use of different water resources. Similarly, property rights should be followed more stringently with state presence. This is important because many communal conflicts are tied to issues of land use. Established through the state, more inclusive property rights should be able to mitigate the effects of groundwater access on the use of violence. Thus, higher state presence should dampen the effect of groundwater access on communal violence.

$H(V)$ : The effect of groundwater access on communal violence is smaller in areas with higher state presence.

\section{$\underline{\text { Research Design }}$}

This paper investigates how groundwater affects the likelihood of violent communal conflict. With the main focus on climate variability, existing large-N studies analyzing communal conflict and water scarcity have predominantly employed precipitation data (e.g. Fjelde \& von Uexkull, 2012; Ide et al., 2014; Hendrix \& Salehyan, 2012). Yet, this study is interested in more broad analyses of water scarcity, 
which can also take into account information on different water availability. In addition, several studies have relied on water data aggregated to the country-level (Gizelis \& Wooden, 2010; Yoffe et al., 2004). While this is not necessarily a problem for interstate analysis, country-level aggregation poses challenges for the scrutiny of intrastate conflict-even more so when moving to a sub-national unit of analysis. In order to overcome such challenges, this study includes geo-referenced information that allows for an analysis with aggregation levels suitable for the study of communal conflict. The unit of analysis in this study is an annual observation of communal violence incidences per PRIO-GRID cell. A caveat with approach is that one cannot effectively measure the migration mechanisms as people can move between the units of analysis. Compared to administrative regions, grids cell have several advantages: their boundaries are time-invariant, they ease comparisons over a large geographic area, and the findings allow a comparison to the many studies with similar setups. PRIO-GRID cells are based on a GIS shapefile with a global 0.5 by 0.5 decimal degree grid system, which means cells are approximately 55 by 55 kilometers at the Equator (Tollefsen, Strand, \& Buhaug, 2012; Tollefsen, Bahgat, Nordkvelle, \& Buhaug, 2015). ${ }^{3}$ The grid cell's size also relates well to the proposed theoretical mechanisms as it can approximately cover temporary farmer mitigation processes and short-range mobility of pastoralists. ${ }^{4}$

\section{Communal Violence}

The dependent variable communal conflict incidence takes the value of 1 if there was at least one communal conflict event in a given grid cell that year or 0 if otherwise. Fatal incidences of communal clashes typically occur as fatal outbursts, sometimes only lasting several hours. Yet, a conflict between groups can last for very long periods of time and sometimes several years can go by without violent events. It is therefore more appropriate to capture communal violence as annual fatal incidences instead of constructing conflict onsets. The data for the analysis relies on the Uppsala Conflict Data Program Geo-referenced Event Dataset (UCDP GED) (Sundberg \& Melander, 2013; Croicu \& Sundberg, 2016) which is combined with the UCDP Non-State Conflict Dataset to obtain more specific information on communal conflict actors (Sundberg, Eck, \& Kreutz, 2012; Pettersson, 2014). I follow the UCDP definitions, and define communal violence as "the use of arms between two informally organized armed groups, neither of which is the government of a state, which results in at least 25 battle-related deaths in a year"(ibid.). Communal armed groups are groups which are not permanently organized, though they "share a common identification along ethnic, clan, religious, national or tribal lines"(Sundberg et al., 2012). The coding thus includes farmer-herder violence that leads to at least one annual fatality during the studied time period. Based on this coding, the data also includes communal militias which

\footnotetext{
${ }^{3}$ Supplementary material also includes robustness checks with larger grids at 1 by 1 decimal degrees to show that the results are not merely due to the level of aggregation and the chosen modifiable areal units.

${ }^{4}$ Clearly some pastoralists move their livestock over journeys, up to $500 \mathrm{~km}$ within a year, sometimes even with the help of lorries. Yet, the majority of grazing movements in many parts of Africa rely on short-distance movements whereas longer movements occur also over longer time periods (Bassett \& Turner, 2006; McCabe, 2004; Turner et al., 2014).
} 
often carry out violence that represent larger tensions between ethnic groups, for example over the use of agricultural land. ${ }^{5}$ Other work based on this data demonstrates that non-state violence is predominantly tied to issues of territory, with water or agricultural land representing major issues areas (von Uexkull \& Pettersson, 2018). The data therefore captures a very large portion of the type of violence described in case studies on communal violence. A drawback is that this data does not include disputes which might be violent, but do not result in fatalities.

Replicating previous research, I create a subset for Sub-Saharan Africa, but the article also expands the analysis with additional samples covering all of Africa, as well as Africa and the Middle East. ${ }^{6}$ The time period covered for the models is 1990 to 2014 due to limited data for the control variables. Figure 1 shows all incidences of communal conflict for the full sample. While the focus is on the incidences of communal violence, it is important to consider the number of fatalities as well as their distribution. Although leading to much fewer casualties than civil wars, communal violence still accounts for thousands of deaths annually. Nigeria, Ethiopia, Somalia, the Sudan, and Kenya are the countries with the most violent communal conflicts, which is also visible through the clustering in those areas. It is apparent that the great majority of events can be found in the Sahel region as well as East Africa. Aside from Central Asia, the region under study includes the major areas for pastoralism in the world. While Africa accounts for the most communal violence globally, the Middle East as a region witnesses far less such violence, sometimes with several years without a single event in the dataset. In contrast to studies which only cover the most violent areas, this article aims to avoid selection bias by covering all relevant areas, including those data relating to counter-factuals or non-occurrences.

\section{Groundwater}

The depth of a well is naturally restricted by the existing geology, but also by the means available for drilling. Some exceptions aside, hand-drilling is limited to well depths of around $50 \mathrm{~m}$, as seen for instance in technical reports and drilling manuals disseminated by the Red Cross, UNICEF, or USAID (Misstear, Banks, \& Clark, 2017; Nwankwoala \& Udom, 2011; ICRC, 2010; van der Wal, 2010). In some areas shallow wells are only seasonally operational, whereas deeper hand dug wells or boreholes are

\footnotetext{
${ }^{5}$ This operationalization foremost excludes conflict between other non-state actors with a high level of organization, e.g. rebel groups such as Al-Shabaab or Boko Haram are not included. Communal violence also excludes electoral violence, such as between political parties or their candidates. Political groups are typically not permanently organized as perpetrators of armed conflict, yet they are more formally organized, which can be exploited for the use of violence (Sundberg et al., 2012). Brosché and Elfversson (2012) provide more in-depth discussion on the concept of communal violence and to what extant this communal violence is captured through UCDPs coding. Please also see Eck (2012) for a comparison to other conflict data projects.

${ }^{6} \mathrm{I}$ follow the UCDP coding for regions. As of August 2018, UCDP GED has not released information on Syria. Based on pre-released data, grid-cell years for Syria are coded as zero for the period 1989 to 2010 since UCDP has not documented any non-state conflict events for this period. Grid cell-years after 2010 are coded as missing for Syria. To exclude potential spillovers, I tested models with a Syria dummy for grid cells adjacent to the Syrian border (see supplementary material).

${ }^{7}$ Figure created by the author with data from UCDP (Sundberg, Eck, \& Kreutz, 2010; Croicu \& Sundberg, 2016) and de Graaf et al. (2015).
} 
Figure 1: Incidences of Communal Conflict and Depth to Groundwater in Africa and the Middle East, 1990 to $2014^{7}$

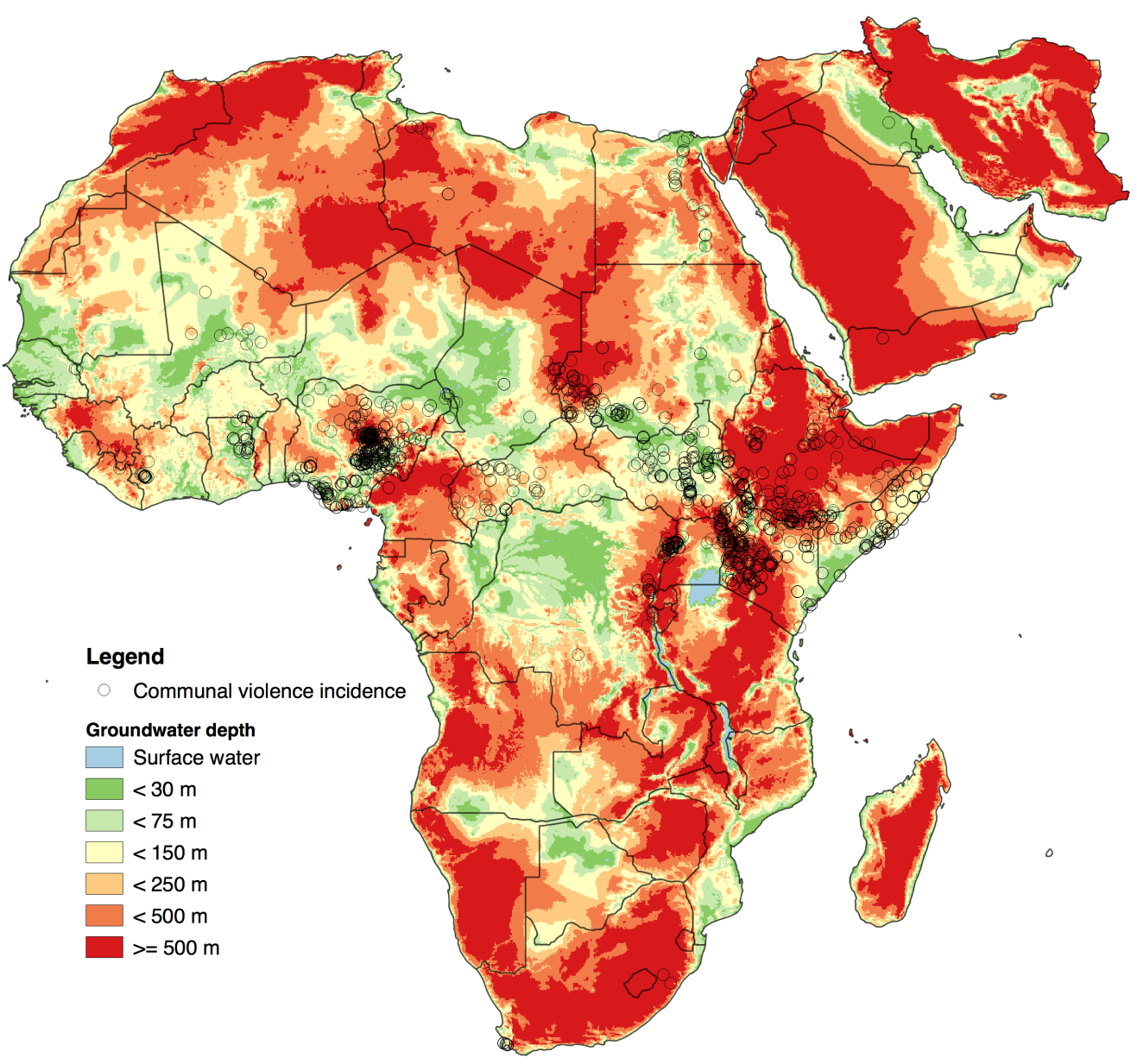

available throughout the year (MacDonald, Calow, Macdonald, Darling, \& Dochartaigh, 2009). For example, Masai in Kenya dig about $5 \mathrm{~m}$ deep seasonal wells in dry riverbeds. For year-round water provision these groups would rather use deeper wells in proximity to villages; for instance, Mbulu groups have constructed 30m hand-dug for Masai wells in exchange for money (Rutten, 2005). Deeper boreholes are more frequently found in smaller towns and generally more urban sites. Nonetheless, wells with depths of 100 or $200 \mathrm{~m}$ are used both in rural areas across Africa and the Middle East(Shahin, 2002, 2007; Tuinhof et al., 2011). In Yemen, for instance, boreholes with such depths have long been used both for nutrition and irrigation. Unregulated drilling and extraction has however also lead to over-exploitation and a spread of community driven regulations (Taha, Bruns, Bamaga, Al-Weshali, \& van Steenbergen, 2012). Following World Bank estimates, relatively affordable tubewells are used more often in water supplies for small-towns in Africa, e.g. in boreholes that reach 250m deep aquifers. Cheaper alternatives for domestic and small villages typically do not exceed 50m deep wells (Tuinhof et al., 2011; World Bank, 2018). Thus, even in rural communities where groundwater is only available at deeper aquifers, a variety of different wells may provide water. Somalia serves a good example. While 
the country has been hit hard through years of civil war and mismanagement of water resources, the majority of wells are manually constructed. Nonetheless, relatively deep boreholes are found throughout the country, both in urban and rural settings where they serve as important buffers in times of extended drought. The majority of boreholes in Somalia are between $15 \mathrm{~m}$ and $200 \mathrm{~m}$ deep, with some even reaching up to 450m depths (FAO-SWALIM, 2012; Basnyat, 2007; Muthusi, Mahamud, Abdalle, \& Gadain, 2007). ${ }^{8}$. Whether in Somalia, Yemen or elsewhere, where groundwater is available to people, they will find a way to extract it. But, where groundwater is more scarce and only accessible at greater depths, community water supplies also face a higher burden.

I capture groundwater access in three ways which are tested in separate models in order to provide more robust results. For a given grid cell, the variable Groundwater In represents the natural log of the average annual depth in meters to the groundwater table. Figure 1 shows groundwater access for different depths in meters. There is a strong global and in-sample variation in groundwater access, for example the median groundwater depth for some grid cells in the region under study can reach over $2400 \mathrm{~m}$, which is well beyond depths that are useful for drilling. The variables GW $250 \mathrm{~m}$ and GW $75 m$ are binaries that take the value 1 if the average depth of the groundwater table exceeds 250 meter and 75 meter, respectively [or zero if otherwise]. It is important to note that these variables represent averages for a given grid cell-year, thus even with the $250 \mathrm{~m}$ threshold, a single grid cell can of course include communities with very shallow groundwater as well as places with very deep aquifers. Hence, the $75 \mathrm{~m}$ threshold does not imply that shallow groundwater is assumed to be solely extracted at this depth, but rather that a considerable amount of a grid cell's groundwater must be available for hand-drilling of wells. The groundwater data comes from validated simulations by de Graaf et al. (2015), de Graaf et al. (2017) which was overlaid with PRIO-GRID. ${ }^{9}$ Higher values on the groundwater variables represent more limited access to groundwater in a grid cell-year. The data indirectly also give an indication of the storage of available groundwater aquifers. ${ }^{10}$ The selected threshold are expected

\footnotetext{
${ }^{8}$ Somalia is a good example as it demonstrates how groundwater is used even where state presence is extremely low. FAO publications on Somalia show several individual cases of borehole usage. Complementing other sources of water, such installations are more frequented during droughts. Water points are not only situated in villages or towns, but are also available to pastoralists in more rural settings. A considerable amount of boreholes in Somalia were built in the 1960s, while a majority was constructed in the 1980s by international development organizations, and to some extent the Somali government. The Darar weyne well (220m deep) in Somaliland for instance, serves especially goat herders and was constructed with Chinese aid during the 1980s. The Dbahar borehole $(170 \mathrm{~m})$ was recently drilled with government help and it provides water for "thousands of head of livestock" (Muthusi et al., 2007, p. 57). Recent studies for the Ceel Waaq District (Gedo Region) recommend the drilling boreholes of over $100 \mathrm{~m}$ to support several villages (SWALIM, 2015)

${ }^{9}$ The groundwater data is based on about $10 \mathrm{~km}^{2}$ (measured at the equator) raster data with monthly values until 2010 . The values between 2011 and 2014 were linearly extrapolated. Separate analyses for the time periods were conducted with similar results [see supplementary material].

${ }^{10}$ In addition, measures for groundwater should also pick up the availability of smaller streams and other types of surface water, including different types of wetlands. The groundwater heads were modeled based surface geology and hydraulic information which only consider aquifers with a productive thickness, i.e., groundwater that is actually useful for human abstraction. Furthermore, the depth to available groundwater is based on modeling with vertical groundwater drainage streams and ground-
} 
to approximately represent whether communities will be able employ manual construction (incl. hand pumps) versus requiring equipment for deeper drilling. Furthermore, many areas in the study might have single boreholes that are much deeper than $250 \mathrm{~m}$. Because deeper drilling and pumping is more expensive, it is assumed that access to such boreholes is more scarce where groundwater tables are on average particularly deep. Everything else equal, access to groundwater is expected to be more common in areas with a lower mean depth to groundwater. Yet, figure 1 reveals that groundwater access and communal violence only correlate in some areas. Instead, other sources of water as well other predictors of communal violence are important elements required for further analyses.

\section{$\underline{\text { Rainfall and Rivers }}$}

This article focuses on access to groundwater and its effect on communal violence. But water scarcity is also determined by the availability of other water sources. Thus all models also include measures for rainfall, drought and major surface water bodies.

Precipitation data comes from the GPCP v.2.2 Combined Precipitation Data Set and gives the annual total amount of precipitation per grid cell (Huffman, Bolvin, \& Adler, 2012). ${ }^{11}$ For the analysis, the values are measured as the natural log of the precipitation in millimeter. As yearly values cannot account for intra-annual variability, rainfall data is only a very rough estimator for water availability. As a consequence, I also include a binary measure for drought to account for seasonal rainfall and climate variation, i.e., 1 represents cells with drought during the rainy season and 0 otherwise. The data is based on SPEI measures from Beguería, Vicente-Serrano, and Angulo-Martínez (2010) which captures the severity of drought for each cell's rainy season as defined in Schneider et al. (2015). ${ }^{12}$ I follow von Uexkull et al. (2016) by only measuring SPEI values equal or smaller than -1 with a binary variable. Additionally, I control for temperature given as the annual mean in centigrade per grid cell (Fan \& van den Dool, 2008) because excluding temperature variables induces biases to climate models with precipitation data (Auffhammer, Hsiang, Schlenker, \& Sobel, 2013). Data on precipitation and drought are available through PRIO-GRID (Tollefsen et al., 2015; Tollefsen et al., 2012).

To capture access to surface water, a dummy variable takes the value 1 if a grid cell intersects with or includes at least one major, perennial river (Natural Earth data) or a reservoir of dams and lakes

\footnotetext{
water storage measures.

${ }^{11}$ The GPCP combined precipitation data were developed and computed by the NASA/Goddard Space Flight Center's Laboratory for Atmospheres as a contribution to the GEWEX Global Precipitation Climatology Project. The GPCP data was provided by the NOAA/OAR/ESRL PSD, Boulder, Colorado, USA, from their web site at http://www.esrl.noaa.gov/psd/.

${ }^{12}$ Drought severity is given by the SPEI value for the last month the rainy season. This is based on the Standardized Precipitation and Evapotranspiration Index SPEI-3 from the SPEIbase (Beguería et al., 2010). The mean value for SPEI is 0, and the standard deviation is 1 . As this is a standardized variable, SPEI values are spatially and temporally comparable. For each month, the index reflects the deviation from long-term normal rainfall during the three preceding months. The SPEI estimation technique based on the Penman-Montheith method is considered better than the frequently used Thornthwaite estimation (Tollefsen et al., 2015).
} 
(Lehner et al., 2011). This surface water measure is the only variable that is not time-variant. While the path of a river or the extent of a reservoir can be altered over time, it is unlikely that such change would be reflected on the chosen unit of analysis. The variable does not capture small streams or other minor surface water bodies; a large amount of such surface water is not perennial which makes it difficult to capture for grid cell-years, especially given the study's spatial and temporal coverage. As groundwater averages will be lower in areas with more surface water, the variables for groundwater should also at least partially account for such non-perennial surface water. Analyses with similar results excluding the surface water variable are provided in the supplementary material. All right hand side variables are lagged by one year.

\section{State capacity and Population}

Following the theoretical assumptions, communal violence can also be partially explained by higher population density as well as state presence, i.e., the state's ability to provide public goods, mitigate scarcity and to intervene in conflict. The exploitation of water resources increases with higher greater demand which puts additional pressure on the available water resources. Controlling for population density, I rely on data estimates for people living within the grid cell (Klein Goldewijk, Beusen, van Drecht, \& de Vos, 2011; Goldewijk, Beusen, \& Janssen, 2010). ${ }^{13}$

To account for state presence, I include a measure for calibrated night-time light emissions (Elvidge, Hsu, Baugh, \& Ghosh, 2014). ${ }^{14}$ In many African and Middle-Eastern states, government activity can be traced based on public goods provision, e.g. visible through increased infrastructure projects (Burgess, Jedwab, Miguel, Morjaria, \& Padró i Miquel, 2015). Including in-situ comparisons in Senegal and Mali, Min (2015) demonstrates how night-time lights are a highly reliable indicator for public goods provision. The same work also shows how this measure translates well to interventions by democratic states and general state presence, even in very rural areas (Min, 2015). Other research also shows how night-time emissions can be utilized to account for state capacity (Koren \& Sarbahi, 2018; Hollenbach, Wibbels, \& Ward, 2016) and local wealth (Weidmann \& Schutte, 2017). While this is perhaps not the perfect measure for state activity, the advantage is that the data is available sub-nationally and most importantly with large geographic and temporal coverage. ${ }^{15}$ Robustness tests also include models using country measures for property rights. This data comes from the Varieties of Democracy project

\footnotetext{
${ }^{13}$ This is available for ten-year intervals; missing data values were linearly interpolated. A caveat with population figures is that they might correlate with media reporting on violence (Weidmann, 2016).

${ }^{14}$ Image and data processing by NOAA's National Geophysical Data Center. DMSP data collected by US Air Force Weather Agency. Values are standardized to be between 0 and 1, where 1 is the highest value in the time-series, and 0 is the lowest; values that are calibrated for inter-satellite differences and inter-annual sensor decay are considered better for time-series analysis (Tollefsen et al., 2015).

${ }^{15}$ An alternative sub-national approach could be utilizing survey data, for example to capture institutional quality (Wig \& Tollefsen, 2016; Linke, Witmer, O'Loughlin, McCabe, \& Tir, 2018). However, this would restrict the analysis to those districts with available survey data.
} 
(V-Dem) (Coppedge et al., 2018). The variable property rights captures to what extent citizens enjoy the right to private property, taking into account limitations through customary law or existing practices (Pemstein et al., 2018). The variable is based on factor analysis and coded from 0 to 1 with higher values representing more rights being protected. The results with the alternative specifications also hold and can be found in the appendix.

\section{Control variables}

The model also includes temporal and spatial controls for incidences of communal conflict and other forms of violence. Communal conflicts can emerge or intensify after civil war (Brosché, 2014). In addition, civil wars can have devastating consequences for water infrastructure, e.g. by destroying piping, sewage plants or simply by cutting of settlements from water supply. Thus, the model includes a dummy variable that takes the value 1 if there was at least one intrastate battle-death in a grid cell-year that is part of an ongoing civil war (based on UCDP coding). To account for potential serial auto-correlation, the model includes Carter-Signorino polynomials of spells without fatal incidences (Carter \& Signorino, 2010; Beck, Katz, \& Tucker, 1998). Furthermore, communal violence might be explained by neighboring disputes. Thus, I capture possible spatial dependence by separately controlling for whether neighboring grid cells (roughly equivalent to a radius of $150 \mathrm{~km}^{2}$ ) have witnessed civil war events, and communal conflict events. The appendix also includes models with spatial error terms.

Unless stated otherwise, all other control variables are taken from data available through PRIOGRID (Tollefsen et al., 2015; Tollefsen et al., 2012). Higher level of development decreases the likelihood of violence and can mitigate problems with water scarcity. Built on the G-Econ dataset (Nordhaus, 2006), GDP is measured per grid cell, i.e., the variable GCP indicates the gross cell product in US dollars employing purchasing-power-parity. Communal violence is frequently the outcome of group exclusion (Fjelde \& Østby, 2014). It is also possible that more marginalized groups simply settle in more waterscarce areas due to different livelihood choices. To control for presence of marginalized groups, the binary variable Excluded takes the value 1 if there has been one or more excluded groups in a given grid cell-year. Excluded groups-discriminated or powerless- are defined according to the GeoEPR/EPR dataset which includes information on the status and location of politically relevant ethnic groups (Vogt et al., 2015).

\section{Empirical Findings}

This section presents the findings on the effect of groundwater on incidences of communal violence. All results build on two-level mixed-effect logistic estimation which models intra-cluster correlation, treating grid cells as as nested clusters of random effects to account for unobserved variation. Models are estimated for Sub-Saharan Africa (to replicate previous research findings), for all of Africa, and 
Table 1: Results from Mixed-Effects Logit Regression: Communal Violence Incidences in Africa and the Middle East, 1990-2014

\begin{tabular}{|c|c|c|c|c|c|c|}
\hline & $\begin{array}{c}(1) \\
\text { SSA }\end{array}$ & $\begin{array}{c}(2) \\
\text { Full }\end{array}$ & $\begin{array}{c}(3) \\
\text { SSA }\end{array}$ & $\begin{array}{c}(4) \\
\text { Full }\end{array}$ & $\begin{array}{c}(5) \\
\text { SSA } \\
\end{array}$ & $\begin{array}{c}(6) \\
\text { Full }\end{array}$ \\
\hline Groundwater ln & $\begin{array}{c}1.362^{* * *} \\
(0.080)\end{array}$ & $\begin{array}{c}1.335^{* * *} \\
(0.072)\end{array}$ & & & & \\
\hline GW 250m dummy=1 & & & $\begin{array}{c}2.028^{* * *} \\
(0.322)\end{array}$ & $\begin{array}{c}1.735^{* * *} \\
(0.267)\end{array}$ & & \\
\hline GW 75m dummy=1 & & & & & $\begin{array}{c}1.590^{* * *} \\
(0.194)\end{array}$ & $\begin{array}{c}1.642^{* * *} \\
(0.199)\end{array}$ \\
\hline River/lake dummy $=1$ & $\begin{array}{c}1.212 \\
(0.152)\end{array}$ & $\begin{array}{l}1.349^{*} \\
(0.170)\end{array}$ & $\begin{array}{c}1.181 \\
(0.149)\end{array}$ & $\begin{array}{l}1.309^{*} \\
(0.166)\end{array}$ & $\begin{array}{c}1.202 \\
(0.151)\end{array}$ & $\begin{array}{l}1.329^{*} \\
(0.168)\end{array}$ \\
\hline Precipitation $\ln (\mathrm{GPCP})$ & $\begin{array}{c}1.046 \\
(0.085)\end{array}$ & $\begin{array}{c}1.384^{* * *} \\
(0.095)\end{array}$ & $\begin{array}{c}1.002 \\
(0.079)\end{array}$ & $\begin{array}{c}1.341^{* * *} \\
(0.091)\end{array}$ & $\begin{array}{c}0.994 \\
(0.078)\end{array}$ & $\begin{array}{c}1.348^{* * *} \\
(0.091)\end{array}$ \\
\hline Drought dummy $=1$ & $\begin{array}{c}0.931 \\
(0.109)\end{array}$ & $\begin{array}{c}0.991 \\
(0.112)\end{array}$ & $\begin{array}{c}0.941 \\
(0.110)\end{array}$ & $\begin{array}{c}0.999 \\
(0.113)\end{array}$ & $\begin{array}{c}0.940 \\
(0.110)\end{array}$ & $\begin{array}{c}0.997 \\
(0.113)\end{array}$ \\
\hline Excluded dummy=1 & $\begin{array}{c}1.981^{* * *} \\
(0.210)\end{array}$ & $\begin{array}{c}1.851^{* * *} \\
(0.195)\end{array}$ & $\begin{array}{c}1.975^{* * *} \\
(0.209)\end{array}$ & $\begin{array}{c}1.838^{* * *} \\
(0.194)\end{array}$ & $\begin{array}{c}1.959^{* * *} \\
(0.207)\end{array}$ & $\begin{array}{c}1.830^{* * *} \\
(0.192)\end{array}$ \\
\hline Nightlights ln & $\begin{array}{c}1.675^{* * *} \\
(0.120)\end{array}$ & $\begin{array}{c}1.585^{* * *} \\
(0.109)\end{array}$ & $\begin{array}{c}1.657^{* * *} \\
(0.118)\end{array}$ & $\begin{array}{c}1.553^{* * *} \\
(0.105)\end{array}$ & $\begin{array}{c}1.660^{* * *} \\
(0.118)\end{array}$ & $\begin{array}{c}1.563^{* * *} \\
(0.106)\end{array}$ \\
\hline $\mathrm{GCP} \ln (\mathrm{PPP})$ & $\begin{array}{l}0.852^{* *} \\
(0.048)\end{array}$ & $\begin{array}{c}0.724^{* * *} \\
(0.039)\end{array}$ & $\begin{array}{l}0.863^{* *} \\
(0.048)\end{array}$ & $\begin{array}{c}0.731^{* * *} \\
(0.039)\end{array}$ & $\begin{array}{l}0.854^{* *} \\
(0.047)\end{array}$ & $\begin{array}{c}0.734^{* * *} \\
(0.039)\end{array}$ \\
\hline Temperature & $\begin{array}{c}1.108^{* * *} \\
(0.019)\end{array}$ & $\begin{array}{c}1.148^{* * *} \\
(0.017)\end{array}$ & $\begin{array}{c}1.081^{* * *} \\
(0.016)\end{array}$ & $\begin{array}{c}1.122^{* * *} \\
(0.015)\end{array}$ & $\begin{array}{c}1.081^{* * *} \\
(0.017)\end{array}$ & $\begin{array}{c}1.125^{* * *} \\
(0.015)\end{array}$ \\
\hline Population density $\ln (\mathrm{GPW})$ & $\begin{array}{c}1.790^{* * *} \\
(0.123)\end{array}$ & $\begin{array}{c}1.965^{* * *} \\
(0.134)\end{array}$ & $\begin{array}{c}1.777^{* * *} \\
(0.120)\end{array}$ & $\begin{array}{c}1.953^{* * *} \\
(0.132)\end{array}$ & $\begin{array}{c}1.799^{* * *} \\
(0.121)\end{array}$ & $\begin{array}{c}1.940^{* * *} \\
(0.130)\end{array}$ \\
\hline State-based viol. time lag $=1$ & $\begin{array}{c}0.930 \\
(0.235)\end{array}$ & $\begin{array}{c}0.897 \\
(0.226)\end{array}$ & $\begin{array}{c}0.930 \\
(0.236)\end{array}$ & $\begin{array}{c}0.899 \\
(0.227)\end{array}$ & $\begin{array}{c}0.912 \\
(0.231)\end{array}$ & $\begin{array}{c}0.886 \\
(0.224)\end{array}$ \\
\hline Civil war viol. spatial lag $=1$ & $\begin{array}{l}1.454^{* *} \\
(0.172)\end{array}$ & $\begin{array}{l}1.372^{* *} \\
(0.160)\end{array}$ & $\begin{array}{c}1.504^{* * *} \\
(0.177)\end{array}$ & $\begin{array}{l}1.418^{* *} \\
(0.165)\end{array}$ & $\begin{array}{c}1.504^{* * *} \\
(0.177)\end{array}$ & $\begin{array}{l}1.414^{* *} \\
(0.164)\end{array}$ \\
\hline Non-state viol. spatial lag=1 & $\begin{array}{c}4.561^{* * *} \\
(0.459)\end{array}$ & $\begin{array}{c}4.777^{* * *} \\
(0.484)\end{array}$ & $\begin{array}{c}4.564^{* * *} \\
(0.460)\end{array}$ & $\begin{array}{c}4.807^{* * *} \\
(0.489)\end{array}$ & $\begin{array}{c}4.621^{* * *} \\
(0.465)\end{array}$ & $\begin{array}{c}4.833^{* * *} \\
(0.490)\end{array}$ \\
\hline Time since last incidence & $\begin{array}{c}0.742^{* * *} \\
(0.031)\end{array}$ & $\begin{array}{c}0.729^{* * *} \\
(0.030)\end{array}$ & $\begin{array}{c}0.741^{* * *} \\
(0.031)\end{array}$ & $\begin{array}{c}0.729^{* * *} \\
(0.030)\end{array}$ & $\begin{array}{c}0.739^{* * *} \\
(0.031)\end{array}$ & $\begin{array}{c}0.728^{* * *} \\
(0.030)\end{array}$ \\
\hline Time sq & $\begin{array}{c}1.017^{* * *} \\
(0.004)\end{array}$ & $\begin{array}{c}1.018^{* * *} \\
(0.004)\end{array}$ & $\begin{array}{c}1.017^{* * *} \\
(0.004)\end{array}$ & $\begin{array}{c}1.019^{* * *} \\
(0.004)\end{array}$ & $\begin{array}{c}1.017^{* * *} \\
(0.004)\end{array}$ & $\begin{array}{c}1.019^{* * *} \\
(0.004)\end{array}$ \\
\hline Time cu & $\begin{array}{l}0.973^{*} \\
(0.010)\end{array}$ & $\begin{array}{l}0.971^{* *} \\
(0.010)\end{array}$ & $\begin{array}{l}0.973^{*} \\
(0.010)\end{array}$ & $\begin{array}{c}0.970^{* *} \\
(0.010)\end{array}$ & $\begin{array}{l}0.973^{*} \\
(0.010)\end{array}$ & $\begin{array}{c}0.970^{* *} \\
(0.010)\end{array}$ \\
\hline Grid cell & $\begin{array}{c}13.563^{* * *} \\
(4.667)\end{array}$ & $\begin{array}{c}19.827^{* * *} \\
(7.305)\end{array}$ & $\begin{array}{c}14.241^{* * *} \\
(4.870)\end{array}$ & $\begin{array}{c}22.453^{* * *} \\
(8.468)\end{array}$ & $\begin{array}{c}13.484^{* * *} \\
(4.575) \\
\end{array}$ & $\begin{array}{c}20.453^{* * *} \\
(7.547) \\
\end{array}$ \\
\hline Observations & 164,463 & 244,166 & 164,463 & 244,166 & 164,463 & 244,166 \\
\hline bic & 7363.523 & 7790.749 & 7375.009 & 7809.841 & 7379.970 & 7805.663 \\
\hline
\end{tabular}


for the full sample which includes Africa and the Middle East. Furthermore, additional models with interaction terms for precipitation, drought, and population density were computed for the same regional samples. The results in this section are presented graphically as odds ratios or marginal effects. Such reporting is particularly warranted for models with interactive terms (Brambor, Clark, \& Golder, 2006; Braumoeller, 2004). The main results can be found in table 1. Additional tables with regression estimates along with robustness checks can be found in the supplementary material.

Interpreting the effect of groundwater access on communal violence (Hypothesis I), the results reveal that the probability of communal violence increases in cells with deeper groundwater head tables, everything else equal. In other words with every extra meter to dig or to drill for water, the likelihood of violent communal conflict increases. This effect is statistically significant in all models. Figure 2a displays the odds ratios for the respective effects of groundwater, drought, and precipitation for all three samples with $95 \%$ confidence intervals. The figure also shows that the effect of the groundwater variable is very similar in all models. Looking at the sample covering Africa, the odds of a communal violence increase on average by about 36 percent for a one-unit change of the groundwater variable, for example when moving from 30 meters to about 55 meters depth to the first available groundwater. Considering the binary variables, the odds of fatal communal violence are more than doubled in areas with average depths to groundwater beyond $250 \mathrm{~m}$ as compared to those below that threshold (Figure 3). In substantive terms however, the probability of conflict incidence only increases by approximately 1 percentage point for changes in the independent variable, holding everything else at their mean values. This is perhaps not entirely surprising, given that other factors like economic development or previous experience with armed conflict are strong predictors for communal violence incidence. Nonetheless, the results from the models suggest that providing groundwater access is a significant factor that mitigates communal violence.

Although, the focus of this paper is on groundwater, I briefly consider the effect of other water related variables in the model. The results show that communal conflict seems to be more likely in proximity to rivers and lakes (not though for the Sub-Saharan Africa sample). This is an interesting finding considering that all models control for economic activity and population density, which should be higher around major freshwater bodies. As in several previous research findings, there is a mixed picture for the effects of precipitation: for the Sub-Saharan Africa sample, rainfall (low or high) does not seem to be a good predictor for communal violence; however, when looking at the full sample, higher amount of rainfall increase the likelihood of communal conflict. This, is a somewhat surprising finding; yet this relationship could be explained by impact of flooding on conflict, or higher likelihood of cattle raiding during more wet seasons as argued in previous studies. None of the models show the used measure for drought as a statistically significant predictor of communal conflict incidence, which is also in line with the literature that shows the effect of drought to be conditional on other socio-economic factors. 


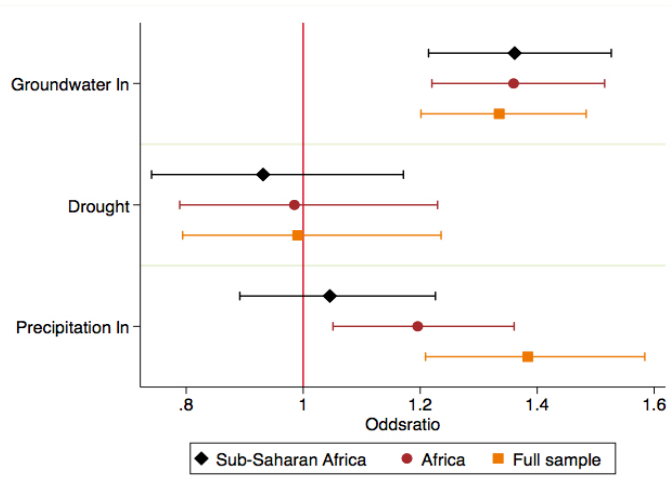

(a) Odds ratios for different samples

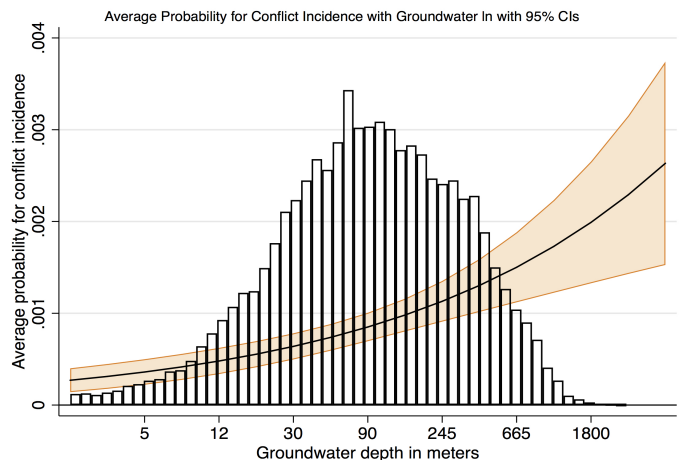

(b) Average probability for Groundwater $\ln$

Figure 2a shows the odds ratios for three different samples (Sub-Saharan Africa, Africa, and the full sample). Figure 2b shows the average probability on conflict for different values of Groundwater overlaid with the sample distribution; other covariates are held at their mean.

A different picture emerges when interpreting the conditional hypotheses II and III, i.e., testing the effect of on communal violence as a function of groundwater and drought as well as groundwater and precipitation. While there is some evidence that groundwater access conditions the effect of precipitation on communal violence (and vice versa), there is no such evidence throughout the interactive models with the drought variable (hypothesis II). Focusing on hypothesis III the results differ depending on the used sample (compare figure 4). For the sample covering Sub-Saharan Africa (Figure 4a), the curve displays the expected causal direction and the effect is statistically significant for relevant values. This is in line with hypothesis III which proposed that the effect of groundwater access will be larger for low rainfall areas. Put differently, this suggests that the effect of scarce groundwater on communal conflict decreases with higher levels of rainfall. However, this relationship turns when using the Africa sample or with the full sample including the Middle East (4b). This highlights the importance of testing across different samples. An important difference is that effect size on communal violence is higher for the Sub-Saharan sample, i.e., although the relationship turns, the effect of groundwater conditional on rainfall is much smaller for the full sample as compared to the sample for Sub-Saharan Africa. By including grid cells from Northern Africa and the Middle, the sample also significantly increases the amount of desert areas. In comparison to larger amount of very arid regions, the conditional effect increases in more humid areas which are also more inhabited. It is also possible that this conditional effect only holds in Sub-Saharan Africa because this area is more reliant on rain-fed agriculture, and thereby more affected by climate variability and shifting seasons. Countries in Northern Africa and the Middle East, on the other hand, have more conservatory water infrastructure that better utilizes irrigation from dams and groundwater. In fact, this region has seen the spread of modern wells with motorized pumps for several decades; even in rural areas, access to water is at a higher level than compared to 
Figure 3: Communal Violence, 1990-2014, Odds Ratios

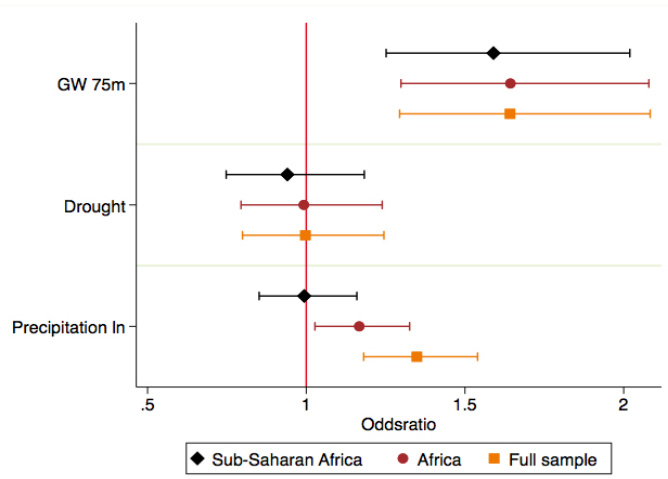

(a) Groundwater dummy 75m, for different samples

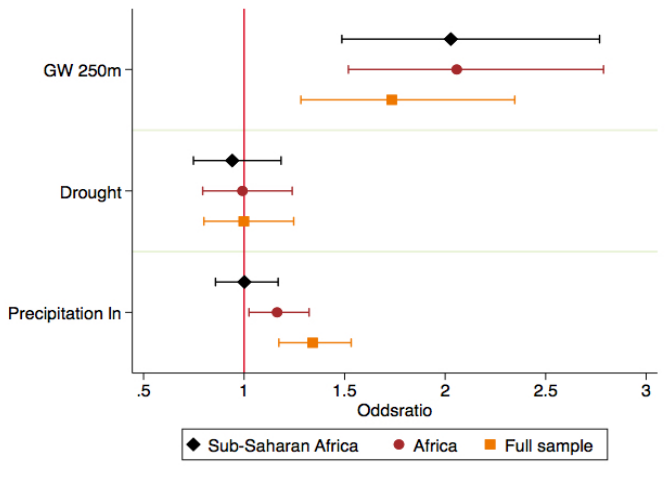

(b) Marginal Effects for Groundwater 250m, for different samples

Figure $3 \mathrm{a}$ and $3 \mathrm{~b}$ show the results as odds ratios for three different samples (Sub-Saharan Africa, Africa, and the full sample) for models explaining communal violence with a dummy variable capturing the mean depth to groundwater thresholds $75 \mathrm{~m}$ and $250 \mathrm{~m}$, respectively. Estimates for drought and precipitation (logged) are also reported.

Sub-Saharan Africa (FAO-Worldbank, 2018).

Patterns for different samples can also be found for hypothesis IV, which theorized that the effect of groundwater will be larger in more densely populated areas. The results displayed in figures $5 \mathrm{a}$ and $5 \mathrm{~b}$ lend support to this hypothesis, showing that the effect of groundwater access on communal conflict increases with higher values for population density. This holds for all samples used in this analysis. Not surprisingly, however, for very high values of population density, the effect is no longer statistical significant at the 95 percent confidence level. This should be expected because cities are naturally not where communal violence takes place. Yet, these findings suggest that water management becomes even more important in regions with rising population and increased urbanization.

The study also finds support for the effect of groundwater access on communal violence being conditional on the level of state presence (hypothesis V). Whether measured as public goods provision or property rights, the models suggest higher state presence to decrease the effect of groundwater access on violence. This holds for the full sample as well as the sub-sample only including Sub-Sahara Africa (Figures for the sub-samples are in the appendix). Night-time light emissions have been used to proxy for public goods provision which is extended to state presence (See also Min, 2015). Figure 4a shows that the effect of groundwater access on communal violence decreases in areas with higher state presence (or higher amounts of night-time emissions). However, very high values do not seem to have a statistically significant effect for this relationship. A very similar pattern emerges when moving to figure $6 \mathrm{~b}$ which shows how the effect of groundwater access on communal violence differs across values on the property rights scale. The effect of groundwater access on violence decreases for higher values, i.e., more property rights. Also here, the effect is no longer statistically significant for very high values of property rights. Thus, after reaching a specific threshold, even higher public goods or increased 
Figure 4: Communal Violence as a function of Groundwater and Precipitation

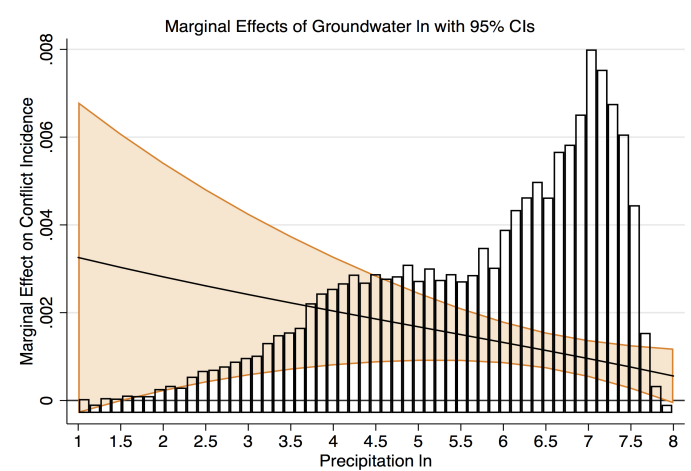

(a) Groundwater and Precipitation (Sub-Saharan Africa)

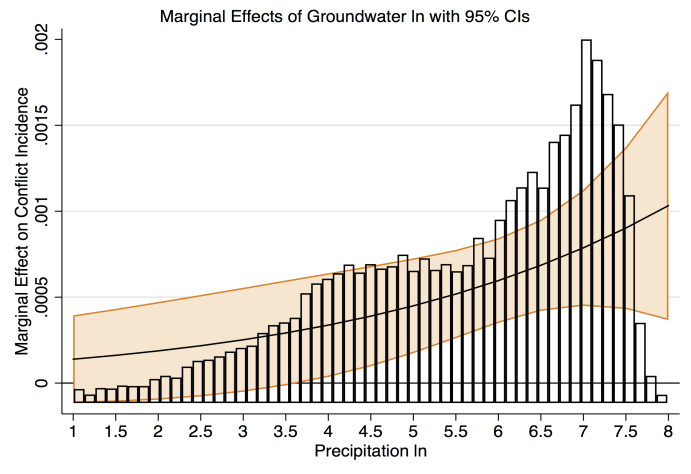

(b) Groundwater and Precipitation (Full sample)

Figure a) and b) show the average marginal effects for conflict as a function of groundwater access and precipitation. The sample for figure a) covers Sub-Saharan Africa, and figure b) displays the full sample results. The subplots show the distribution of the precipitation in the respective sample.

state presence does not seem to affect how groundwater access links to communal violence. These results are in line with the proposed arguments that increased state presence should mitigate the effect of groundwater on violence.

Most control variables show the expected relationship patterns. Marginalized groups and previous incidences of violence (and in the same or neighborhood) are robust predictors of communal violence. Population density also explains higher likelihood of communal violence. Particularly violence in the neighboring area, both civil war events and other non-state actor fighting, increase the likelihood of communal violence significantly. On the other hand, economic development, measured through GCP, decreases incidences of conflict as was expected. 
Figure 5: Communal Violence as a function of Groundwater and Population density
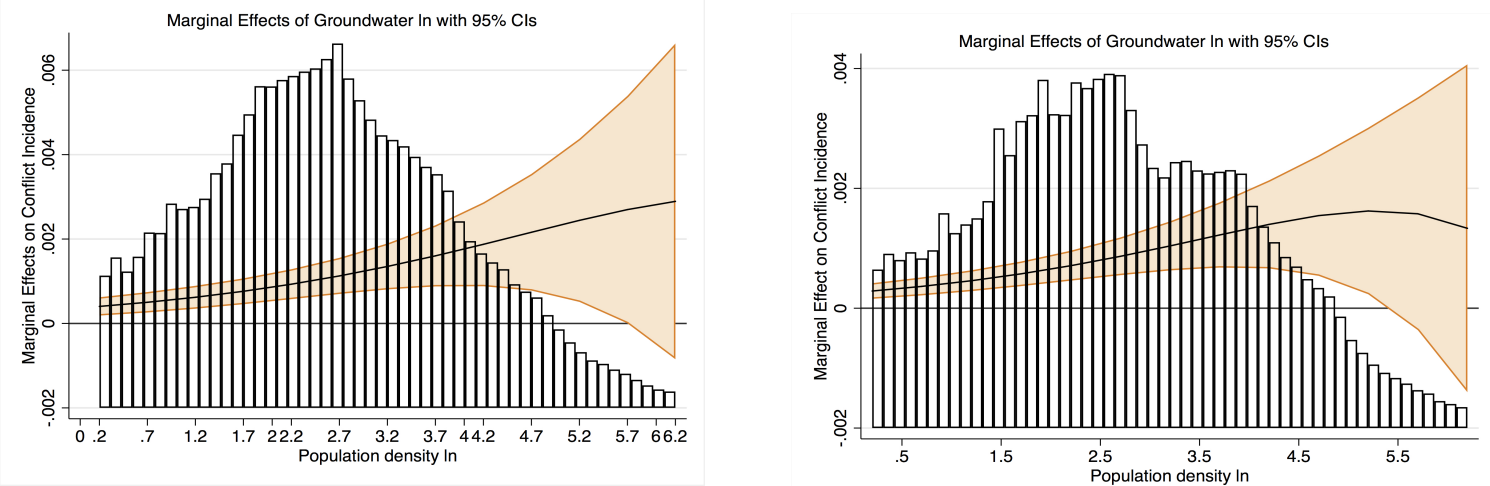

(a) Groundwater and Population density (Sub-Saharan Africa)

(b) Groundwater and Population density (Full sample)

Figure a) and b) show average marginal effects for conflict as a function of groundwater access and population density. The sample for figure a) covers Sub-Saharan Africa, and figure b) displays the full sample results. The subplots show the distribution of the population density in the respective sample.

Figure 6: Communal Violence as a function of Groundwater and State Presence

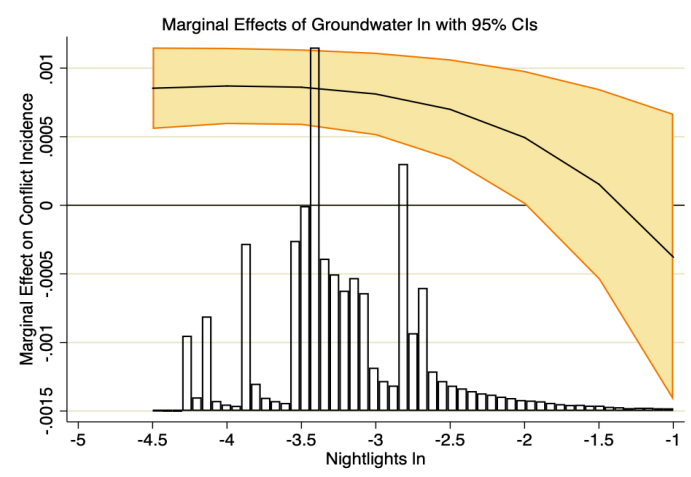

(a) Groundwater and State Presence (Full sample)

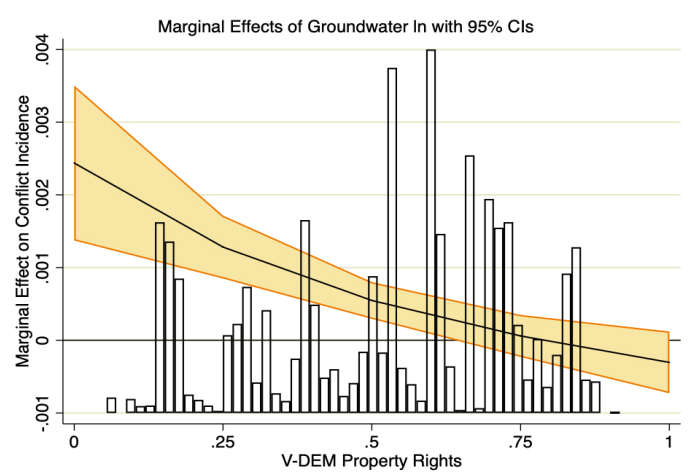

(b) Groundwater and State Presence(Full sample)

Figure a) and b) show the average marginal effects for conflict as a function of groundwater access and state presence, measure as nightlight emission and V-DEMs measure for property rights. Both figures show the effects for the full sample. The subplots show the distribution of the variables. 


\section{Conclusions}

This article empirically analyzed the relationship between groundwater scarcity and incidences of communal violence. Groundwater constitutes half of global drinking water and represents a major buffer for communities in times of drought. For the study of communal violence and water scarcity, it is vital to analyze different water sources that can mitigate climate-related dry spells. This is the first study that explicitly deals with groundwater resources and armed conflict while also accounting for other water resources. Using novel data and expanding the geographic area of previous studies, this work highlights the importance of different types of water resources for communal violence. All measures capturing groundwater scarcity show that lacking access to groundwater increases the likelihood of communal violence. This holds for all samples, covering Africa and the Middle East as well as subsamples only for Africa and Sub-Saharan Africa, respectively. There are mixed results for the conditional effects of groundwater and precipitation. In Sub-Saharan Africa, having both low rainfall and low access to groundwater means the likelihood of communal conflict increases in comparison to areas where either water source is more abundant. This, however, does not hold for the full sample including all of Africa and the Middle East. Furthermore, securing safe access to groundwater is crucial in more populous areas because the likelihood of communal violence is particularly increased with both more difficult access to groundwater and high population density. The study also finds that state presence and the provision of public goods dampen the effect of difficult groundwater access on violence. The results of this study highlight the importance of groundwater as a tool for adaption strategies, especially in times of water scarcity. Accounting for the use of groundwater is key for sustainable water management, especially when considering the increase of climate-induced droughts in recent years.

There are several avenues for future work. While this study extended the range of water resources, there are still several other factors that drive water scarcity. Pollution of both surface and below-surface water endangers the safe use of these resources. In addition, sea water intrusion has become more common, especially for aquifers close to urbanized coastal zones. These factors need to be better accounted for when assessing the impact of water scarcity. For further analysis, it will be important to consider the impact of surface water, especially at more disaggregated levels, e.g. the importance of smaller streams or wetlands. Research also needs to investigate the exact causal mechanisms between groundwater access and communal violence. This could be possible through experimental-design studies as well as in-depth case research which explicitly looks at groundwater in addition to other water sources. While communal violence is more common within the region under study, future research ought to further investigate the possible links in other geographic areas.

As explained by Sustainable Development Goal 6, water scarcity is rightfully one of the most crucial aspects for global development. While there is reliable knowledge on the prevalence of water scarcity on more aggregate levels, it is key to collect more fine-grained and reliable data to allow better assessments and more targeted policy actions. More interventions are urgently needed as there are still more 
than two billion people who lack access to clean freshwater, which has drastic health consequences for those affected. Uncertainty over water supply is further hampered by increasing weather extremes and shifting climate variability. As the pressure on existing water resources increases, it will be crucial to scrutinize the linkages between water scarcity and violence, but also the potential for cooperation over resources. The latter can be achieved through integrated water management, which functions as a key tool to mitigate conflicts over water. However, one cannot manage, what is not properly measured. Thus, both policy making and research would benefit immensely from better access to reliable, sub-national data on available water resources. 


\section{References}

Auffhammer, M., Hsiang, S. M., Schlenker, W., \& Sobel, A. (2013). Using weather data and climate model output in economic analyses of climate change. Review of Environmental Economics and Policy, 7(2), 181-198.

Basnyat, D. B. (2007). Water resources of somalia: Technical report no. w-11. Nairobi, Kenya: FAO-SWALIM.

Bassett, T. J. (1988). The political ecology of peasantherder conflicts in the northern ivory coast. $A n$ nals of the Association of American Geographers, $78(3), 453-472$.

Bassett, T. J. \& Turner, M. D. (2006). Sudden shift or migratory drift? FulBe herd movements to the sudano-guinean region of west africa. Human Ecology, 35(1), 33-49.

Beck, N., Katz, J. N., \& Tucker, R. (1998). Taking time seriously: Time-series-cross-section analysis with a binary dependent variable. American Journal of Political Science, 1260-1288.

Beguería, S., Vicente-Serrano, S. M., \& Angulo-Martínez, M. (2010). A multiscalar global drought dataset: The SPEIbase: A new gridded product for the analysis of drought variability and impacts. Bulletin of the American Meteorological Society, 91(10), 1351-1356.

Benjaminsen, T. A. \& Ba, B. (2009). Farmer-herder conflicts, pastoral marginalisation and corruption: A case study from the inland niger delta of mali. The Geographical Journal, 175(1), 71-81.

Benjaminsen, T. A. \& Lund, C. (2002). Formalisation and informalisation of land and water rights in africa: An introduction. The European Journal of Development Research, 14(2), 1-10

Benjaminsen, T. A., Maganga, F. P., \& Abdallah, J. M. (2009). The kilosa killings: Political ecology of a farmer-herder conflict in tanzania. Development and Change, 40(3), 423-445.
Bernauer, T. \& Böhmelt, T. (2014). Basins at Risk: Predicting International River Basin Conflict and Cooperation. Global Environmental Politics, 14(4), 116138.

Bogale, A. \& Korf, B. (2007, May). To share or not to share? (non-)violence, scarcity and resource access in somali region, ethiopia. The Journal of Development Studies, 43(4), 743-765.

Bogale, A., Taeb, M., \& Endo, M. (2006). Land ownership and conflicts over the use of resources: Implication for household vulnerability in eastern ethiopia. Ecological Economics, 58(1), 134-145.

Böhmelt, T., Bernauer, T., Buhaug, H., Gleditsch, N. P., Tribaldos, T., \& Wischnath, G. (2014). Demand, supply, and restraint: Determinants of domestic water conflict and cooperation. Global Environmental Change, 29, 337-348.

Bollig, M. (1993). Intra-and interethnic conflict in northwest kenya. a multicausal analysis of conflict behaviour. Anthropos, (H. 1./3), 176-184.

Boone, C. (2014). Property and political order in africa. Cambridge, U.K.: Cambridge University Press.

Brambor, T., Clark, W. R., \& Golder, M. (2006). Understanding interaction models: Improving empirical analyses. Political analysis, 63-82.

Braumoeller, B. F. (2004). Hypothesis testing and multiplicative interaction terms. International Organization, 58(04).

Brochmann, M. \& Gleditsch, N. P. (2012). Shared rivers and conflict - A reconsideration. Political Geography, 31(8), 519-527.

Brosché, J. (2014). Masters of war: The role of elites in Sudan's communal conflicts. Uppsala: Uppsala universitet.

Brosché, J. \& Elfversson, E. (2012). Communal conflict, civil war, and the state: Complexities, connec- 
tions, and the case of Sudan. African Journal on Conflict Resolution, 12(1), 9-32.

Buhaug, H., Benjaminsen, T. A., Sjaastad, E., \& Theisen, O. M. (2015). Climate variability, food production shocks, and violent conflict in sub-saharan Africa. Environmental Research Letters, 10(12), 125015.

Burgess, R., Jedwab, R., Miguel, E., Morjaria, A., \& Padró i Miquel, G. (2015). The value of democracy: Evidence from road building in kenya. American Economic Review, 105(6), 1817-1851.

Butler, C. K. \& Gates, S. (2012). African range wars: Climate, conflict, and property rights. Journal of Peace Research, 49(1), 23-34.

Butterworth, J., Sutton, S., \& Mekonta, L. (2013). Selfsupply as a complementary water services delivery model in Ethiopia. Water alternatives, 6(3), 405.

Carter, D. B. \& Signorino, C. S. (2010). Back to the future: Modeling time dependence in binary data. Political Analysis, 18(3), 271-292.

Cederman, L.-E., Gleditsch, K. S., \& Buhaug, H. (2013). Inequality, grievances, and civil war. Cambridge University Press.

Ceola, S., Laio, F., \& Montanari, A. (2015). Humanimpacted waters: New perspectives from global high-resolution monitoring. Water Resources Research, 51(9), 7064-7079.

Collier, P. \& Hoeffler, A. (2004). Greed and grievance in civil war. Oxford Economic Papers, 56(4), 563-595.

Coppedge, M., Gerring, J., Lindberg, S. I., Skaaning, S.-E., Teorell, J., Altman, D., ... Cornell, A., et al. (2018). V-dem codebook v8. Varieties of Democracy (VDem) Project.

Croicu, M. \& Sundberg, R. (2016). Ucdp ged codebook version 5.0. Department of Peace and Conflict Research, Uppsala University.

de Graaf, I. E. M., Sutanudjaja, E. H., van Beek, L. P. H., \& Bierkens, M. F. P. (2015). A high-resolution globalscale groundwater model. Hydrology and Earth System Sciences, 19(2), 823-837 de Graaf, I. E. M., van Beek, R. L., Gleeson, T., Moosdorf, N., Schmitz, O., Sutanudjaja, E. H., \& Bierkens, M. F. (2017). A global-scale two-layer transient groundwater model: Development and application to groundwater depletion. Advances in Water Resources, 102, 53-67.

Detges, A. (2014). Close-up on renewable resources and armed conflict. Political Geography, 42, 57-65.

Detges, A. (2016). Local conditions of drought-related violence in sub-saharan Africa the role of road and water infrastructures. Journal of Peace Research, 696-710.

Detges, A. (2017). Droughts, state-citizen relations and support for political violence in sub-saharan africa: A micro-level analysis. Political Geography, $61,88-98$.

Eck, K. (2012). In data we trust? a comparison of UCDP GED and ACLED conflict events datasets. Cooperation and Conflict, 47(1), 124-141.

Eck, K. (2014). The law of the land: Communal vonflict and legal authority. Journal of Peace Research.

Edmunds, W. M. (2012). Limits to the availability of groundwater in Africa. Environmental Research Letters, 7(2), 021003.

Elfversson, E. (2015). Providing security or protecting interests? government interventions in violent communal conflicts in Africa. Journal of Peace Research, 52(6), 791-805.

Elfversson, E. (2019). The political conditions for local peacemaking: A comparative study of communal conflict resolution in kenya. Comparative Political Studies, 001041401983073.

Elvidge, C. D., Hsu, F.-C., Baugh, K. E., \& Ghosh, T. (2014). National trends in satellite-observed lighting. Global urban monitoring and assessment through Earth observation, 23, 97-118.

Falkenmark, M. (1990). Global water issues facing humanity. Journal of Peace Research, 27(2), 177Ø190. 
Fan, Y. \& van den Dool, H. (2008). A global monthly land surface air temperature analysis for 1948-present. Journal of Geophysical Research, 113(D01103).

FAO-SWALIM. (2012). Hydrogeological survey and assessment of selected areas in somaliland and puntland. technical report no. w-20. fao-swalim (gcp/som/049/ec) project. FAO. Nairobi, Kenya.

FAO-Worldbank. (2018). Water management in fragile systems [Building resilience to shocks and crisis in the middle east and north africa]. Food, Agriculture Organization of the United Nations, and Worldbank. Cairo, Egypt.

Fiddian-Qasmiyeh, E., Ruiz, I., Vargas Silva, C. I., Zetter, R. W., Hoelscher, K., Stave, S. E., \& Zhang, H. (2011). Study on impacts and costs of forced displacemet: State of the art literature review, vol. 2. World Bank. Washington, D.C.

Fjelde, H. \& Østby, G. (2014). Socioeconomic inequality and communal conflict: A disaggregated analysis of sub-saharan Africa, 1990-2008. International Interactions, 40(5), 737-762.

Fjelde, H. \& von Uexkull, N. (2012). Climate triggers: Rainfall anomalies, vulnerability and communal conflict in sub-saharan Africa. Political Geography, 31(7), 444-453.

Foster, S., Tuinhof, A., \& Steenbergen, F. v. (2012). Managed groundwater development for water-supply security in sub-saharan Africa: Investment priorities. Water $S A, 38(3), 359-366$

Fratkin, E. (1994). Pastoral land tenure in kenya: Maasai, samburu, boran, and rendille experiences, 19501990. Nomadic Peoples, (34/35), 55-68. Retrieved from http://www.jstor.org/stable/43124072

Gizelis, T.-I. \& Wooden, A. E. (2010). Water resources, institutions, \&amp; intrastate conflict. Political Geography, 29(8), 444-453.

Goldewijk, K. K., Beusen, A., \& Janssen, P. (2010). Longterm dynamic modeling of global population and built-up area in a spatially explicit way: Hyde 3.1. The Holocene, 20(4), 565-573.
Graeub, B. E., Chappell, M. J., Wittman, H., Ledermann, S., Kerr, R. B., \& Gemmill-Herren, B. (2015). The state of family farms in the world. World development.

Grech-Madin, C., Döring, S., Kim, K., \& Swain, A. (2018). Negotiating water across levels: A peace and conflict "toolbox" for water diplomacy. Journal of Hydrology, 559, 100-109.

Greiner, C. (2013). Guns, land, and votes: Cattle rustling and the politics of boundary (re)making in northern kenya. African Affairs, 112(447), 216-237.

Grönwall, J. (2016). Self-supply and accountability: To govern or not to govern groundwater for the (peri-) urban poor in accra, Ghana. Environmental Earth Sciences, 75(16), 1163.

Gurr, T. R. (1970). Why men rebel. Princeton, NJ: Princeton University Press.

Hagberg, S. (2004). Dealing with dilemmas: Violent farmer-pastoralist conflicts in burkina faso. In P. Richards (Ed.), No peace, no war: An anthropology of contemporary armed conflicts (pp. 40-56). Athens: Ohio University Press.

Hendrix, C. S. \& Salehyan, I. (2012). Climate change, rainfall, and social conflict in Africa. Journal of Peace Research, 49(1), 35-50.

Higazi, A. (2016). Farmer-pastoralist conflicts on the Jos Plateau, central Nigeria: Security responses of local vigilantes and the Nigerian state. Conflict, Security $\mathcal{E}$ Development, 16(4), 365-385.

Hollenbach, F. M., Wibbels, E., \& Ward, M. D. (2016, September 30). State building and the geography of governance: Evidence from satellites. In Working paper. Manuscript, Duke University.

Homer-Dixon, T. (1994). Environmental scarcities and violent conflict: Evidence from cases. International Security, 19(1), 5-40.

Huffman, G. J., Bolvin, D. T., \& Adler, R. (2012). Gpcp version $2.2 \mathrm{sg}$ combined precipitation data set wdc-a, ncdc, asheville, nc. GPCP data. Retrieved June 26, 2015, from ftp : / / precip . gsfc . nasa . 
gov / pub / gpcp - v2 . 2 / psg/. (The GPCP combined precipitation data were developed and computed by the NASA/Goddard Space Flight Center's Laboratory for Atmospheres as a contribution to the GEWEX Global Precipitation Climatology Project. The GPCP data was provided by the NOAA/OAR/ESRL PSD, Boulder, Colorado, USA, from their Web site at http:/ /www.esrl.noaa.gov/psd/.)

ICRC. (2010). Technical review: Borehole drilling and rehabilitation under field conditions. Reference. Geneva, Switzerland: International Commitee of the Red Cross.

Ide, T., Schilling, J., Link, J. S. A., Scheffran, J., Ngaruiya, G., \& Weinzierl, T. (2014). On exposure, vulnerability and violence: Spatial distribution of risk factors for climate change and violent conflict across Kenya and Uganda. Political Geography, 43, 68-81.

Jánszky, B. \& Jungstand, G. (2013). Pastoralism, conflict and the state in contemporary eastern chad: The case of zaghawa-tama relationships. In M. Bollig, M. Schnegg, \& H.-P. Wotzka (Eds.), Pastoralism in africa: Past, present and future (pp. 365-388). Oxford: Berghahn.

Kanyerere, T. O., Nkhata, M. G., \& Mkandawire, T. (2009). Rural water supply and sanitation in malawi: Groundwater context. In Sustainable groundwater resources in africa (pp. 221-233). London: CRC Press, Taylor \& Francis.

Klein Goldewijk, K., Beusen, A., van Drecht, G., \& de Vos, M. (2011). The hyde 3.1 spatially explicit database of human-induced global land-use change over the past 12,000 years. Global Ecology and Biogeography, 20(1), 73-86.

Koren, O. \& Sarbahi, A. K. (2018). State capacity, insurgency, and civil war: A disaggregated analysis. International Studies Quarterly.

Koubi, V., Spilker, G., Schaffer, L., \& Bernauer, T. (2016). Environmental stressors and migration: Evidence from Vietnam. World Development, 79, 197-210.
Kreutz, J. \& Eck, K. (2011). Regime transition and communal violence. In $52^{\text {nd }}$ Convention of the International Studies Association, Montreal (pp. 16-19).

Landis, S. T., Rezaeedaryakenari, B., Zhang, Y., Thies, C. G., \& Maciejewski, R. (2017). Fording differences? conditions mitigating water insecurity in the niger river basin. Political Geography, 56, 77-90

Lehner, B., Liermann, C. R., Revenga, C., Vörösmarty, C., Fekete, B., Crouzet, P., ... Magome, J., et al. (2011). High-resolution mapping of the world's reservoirs and dams for sustainable river-flow management. Frontiers in Ecology and the Environment, 9(9), 494-502.

Linke, A. M., Witmer, F. D. W., O'Loughlin, J., McCabe, J. T., \& Tir, J. (2018). Drought, local institutional contexts, and support for violence in kenya. Journal of Conflict Resolution, 62(7), 1544-1578. eprint: https://doi.org/10.1177/0022002717698018

Lund, C. (2008). Local politics and the dynamics of property in africa. Cambridge University Press.

Lutz, A., Thomas, J. M., Pohl, G., Keita, M., \& McKay, W. A. (2008). Sustainability of groundwater in Mali, west Africa. Environmental Geology, 58(7), 1441-1450.

MacDonald, A. M., Calow, R. C., Macdonald, D. M., Darling, W. G., \& Dochartaigh, B. (2009). What impact will climate change have on rural groundwater supplies in africa? Hydrological Sciences Journal, 54(4), 690-703.

McCabe, J. T. (2004, November 30). Cattle bring us to our enemies. Ann Arbor: University of Michigan Press.

Meier, P., Bond, D., \& Bond, J. (2007). Environmental influences on pastoral conflict in the horn of Africa. Political Geography, 26(6), 716-735.

Min, B. (2015). Power and the vote. New York: Cambridge University Press.

Misstear, B., Banks, D., \& Clark, L. (2017). Water wells and boreholes. Wiley-Blackwell Ebook.

Mujeeb, A.-N. \& John, B. (1992). Livestock development in somalia. GeoJournal, 26(3), 357-362 
Muthusi, F. M., Mahamud, G., Abdalle, A., \& Gadain, H. M. (2007). Rural water supply assessment: Technical report no-08. Nairobi, Kenya: FAO-SWALIM.

Nordhaus, W. D. (2006). Geography and macroeconomics: New data and new findings. Proceedings of the National Academy of Sciences of the United States of America, 103(10), 3510-3517.

Nordkvelle, J., Rustad, S. A., \& Salmivalli, M. (2017). Identifying the effect of climate variability on communal conflict through randomization. Climatic Change, 141(4), 627-639

Nwankwoala, H. \& Udom, G. (2011). Technical challenges for water borehole design, construction and maintenance in the eastern niger delta of nigeria. African Journal of Science, Technology, Innovation and Development, 3(4), 195-209.

Nyong, A. O. \& Kanaroglou, P. S. (1999). Domestic water use in rural semiarid Africa: A case study of katarko village in northeastern Nigeria. Human Ecology, 27(4), 537-555.

O’Loughlin, J., Linke, A. M., \& Witmer, F. D. (2014). Effects of temperature and precipitation variability on the risk of violence in sub-saharan Africa, 1980-2012. Proceedings of the National Academy of Sciences, 111(47), 16712-16717.

O'Loughlin, J., Witmer, F. D., Linke, A. M., Laing, A., Gettelman, A., \& Dudhia, J. (2012). Climate variability and conflict risk in east Africa, 1990-2009. Proceedings of the National Academy of Sciences, 109(45), 18344-18349.

Ostrom, E. (1990). Governing the commons: The evolution of institutions for collective action (political economy of institutions and decisions). Cambridge University Press.

Papaioannou, K. J. (2016). Climate shocks and conflict: Evidence from colonial nigeria. Political Geography, 50, 33-47.

Patience, M. (2016, August 10). Nigeria's deadly battle for land: Herdsmen $v$ farmers. Retrieved from http : / / www. bbc.com / news / world - africa 37021044

Pemstein, D., Marquardt, K. L., Tzelgov, E., Wang, Y.-t., Krusell, J., \& Miri, F. (2018). The v-dem measurement model: Latent variable analysis for crossnational and cross-temporal expert-coded data. University of Gothenburg, Varieties of Democracy Insitute: Working Paper, (21).

Pettersson, T. (2014). Ucdp non-state conflict codebook version 2.5-2016. Uppsala, Uppsala Conflict Data Program, Department of Peace and Conflict Research, Uppsala University.

Post, V., Eichholz, M., \& Brentführer, R. (2018). Groundwater management in coastal zones. Bundesanstalt füer Geowissenschaften (BGR). ISBN 9783-9814108-2-2. Hanover, Germany.

Raleigh, C. (2010). Political marginalization, climate change, and conflict in african sahel states. International studies review, 12(1), 69-86.

Raleigh, C. \& Kniveton, D. (2012). Come rain or shine: An analysis of conflict and climate variability in east Africa. Journal of Peace Research, 49(1), 51-64.

Rutten, M. (2005). Shallow wells: A sustainable and inexpensive alternative to boreholes in kenya (ASC Working Paper No. 66). African Studies Centre Leiden. African Studies Centre P.O. Box 9555, 2300 RB Leiden, The Netherlands. Retrieved December 5, 2016, from https: / / openaccess . leidenuniv.nl / bitstream / handle / 1887 / 9460 / ASC - 1268319 032.pdf

Schneider, U., Becker, A., Finger, P., Meyer-Christoffer, A., Rudolf, B., \& Ziese, M. (2015). Gpcc full data reanalysis version 7.0 at 0.5: Monthly land-surface precipitation from rain-gauges built on gts-based and historic data. Global Precipitation Climatology Centre (GPCC) at Deutscher Wetterdienst.

Searcey, D. (2018, September 23). Nigerian herders' biggest fear: Not lions, but farmers. The New York Times, A6. Retrieved from https:/ / www.nytimes. 
com / 2018 / 09 / 22 / world / africa / africa-nigeriaherders-farmers-battle.html

Shahin, M. (2002). Hydrology and water resources of africa. SPRINGER NATURE.

Shahin, M. (2007). Water resources and hydrometeorology of the arab region. Springer Netherlands.

Siebert, S., Burke, J., Faures, J.-M., Frenken, K., Hoogeveen, J., Döll, P., \& Portmann, F. T. (2010). Groundwater use for irrigation-a global inventory. Hydrology and Earth System Sciences, 14(10), 1863-1880.

Staro, F. (2014). Valuing "indigenous knowledge" related to water usage among garri pastoralists of southern Ethiopia: Which/whose knowledge? African Study Monographs. Supplementary Issue, 48, $49-58$

Steduto, P., Faurès, J.-M., Hoogeveen, J., Winpenny, J., \& Burke, J. (2012). Coping with water scarcity: An action framework for agriculture and food security. Rome, Italy: Food and Agriculture Organization of the United Nations (FAO).

Sundberg, R., Eck, K., \& Kreutz, J. (2010). Ucdp non-state conflict codebook version 2.3-2010. Uppsala, Uppsala Conflict Data Program, Department of Peace and Conflict Research, Uppsala University.

Sundberg, R., Eck, K., \& Kreutz, J. (2012). Introducing the ucdp non-state conflict dataset. Journal of Peace Research, 49, 351-362.

Sundberg, R. \& Melander, E. (2013). Introducing the ucdp georeferenced event dataset. Journal of Peace Research, 50(4), 523-532.

Susskind, L. E., Ali, S. H., \& Hamid, Z. A. (2014). Environmental diplomacy. Oxford University Press.

Swain, A. (1993). Environment and conflict: Analyzing the developing world. Report No. 37. Uppsala, Sweden: Department of Peace and Conflict Research.

Swain, A. (2004). Managing water conflict: Asia, africa and the middle east. Routledge.
Swain, A. (2012). Understanding emerging security challenges: Threats and opportunities. Contemporary Security Studies. Taylor \& Francis.

SWALIM. (2015). Hydrogeological study in ceel waaq district, gedo region, somalia: Technical reportno w-26. Nairobi, Kenya: FAO-SWALIM.

Taha, T., Bruns, B., Bamaga, O., Al-Weshali, A., \& van Steenbergen, F. (2012). Local groundwater governance in yemen: Building on traditions and enabling communities to craft new rules. Hydrogeology Journal, 20(6), 1177-1188.

Tollefsen, A. F., Bahgat, K., Nordkvelle, J., \& Buhaug, H. (2015). Prio-grid v.2.0 Codebook. Peace Research Institute Oslo.

Tollefsen, A. F., Strand, H., \& Buhaug, H. (2012). Priogrid: A unified spatial data structure. Journal of Peace Research, 49(2), 363-374.

Tuinhof, A., Foster, S., van Steenbergen, F., Talbi, A., \& Wishart, M. (2011). Appropriate groundwater management policy for sub-saharan Africa: In face of demographic pressure and climatic variability (Report No. 5). World Bank. Washington, D.C.

Turner, M. D., Ayantunde, A. A., Patterson, K. P., \& Patterson, E. D. (2012, April). Conflict management, decentralization and agropastoralism in dryland west africa. World Development, 40(4), 745-757.

Turner, M. D., Butt, B., Singh, A., Brottem, L., Ayantunde, A., \& Gerard, B. (2014). Variation in vegetation cover and livestock mobility needs in sahelian west africa. Journal of Land Use Science, 11(1), 76-95.

Turner, M. D. \& Moumouni, O. (2018). Mosaics of property: Control of village land in west africa. The Journal of Peasant Studies, 1-25.

UNEP. (2010). Africa water atlas. Nairobi: Division of Early Warning and Assessment, United Nations Environment Programme (UNEP).

van der Wal, A. (2010). Understanding groundwater and wells in manual drilling [Instruction handbook for manual drilling teams on hydro-geology for well 
drilling,well installation and well development]

(2nd ed.). Papendrecht, the Netherlands: Practica Foundation.

Vogt, M., Bormann, N.-C., Ruegger, S., Cederman, L.-E., Hunziker, P., \& Girardin, L. (2015). Integrating data on ethnicity, geography, and conflict: The ethnic power relations data set family. Journal of Conflict Resolution, 59(7), 1327-1342.

von Uexkull, N., Croicu, M., Fjelde, H., \& Buhaug, H. (2016). Civil conflict sensitivity to growing-season drought. Proceedings of the National Academy of Sciences, 201607542.

von Uexkull, N. \& Pettersson, T. (2018). Issues and actors in african nonstate conflicts: A new data set. International Interactions, 44(5), 953-968.

WEF. (2017). The global risks report 2017. World Economic Forum. Geneva, Switzerland. Retrieved from http:/ / wef.ch/risks2017

Weidmann, N. B. (2016). A closer look at reporting bias in conflict event data. American Journal of Political Science, 60(1), 206-218.
Weidmann, N. B. \& Schutte, S. (2017). Using night light emissions for the prediction of local wealth. Journal of Peace Research, 54(2), 125-140. eprint: https: //doi.org/10.1177/0022343316630359

Wig, T. \& Tollefsen, A. F. (2016). Local institutional quality and conflict violence in africa. Political Geography, 53, 30-42.

Wischnath, G. \& Buhaug, H. (2014). On climate variability and civil war in Asia. Climatic Change, 122, 709721.

World Bank. (2018). Assessment of groundwater challenges $\mathcal{E}$ opportunities in support of sustainable development in sub-saharan africa. World Bank Group. Washington, D.C.: The World Bank.

WWAP. (2015). The United Ntions World Water Development Report 2015: Water for a sustainable world. Paris, France: UNESCO.

Yoffe, S., Fiske, G., Giordano, M., Giordano, M., Larson, K., Stahl, K., \& Wolf, A. T. (2004). Geography of international water conflict and cooperation: Data sets and applications. Water Resources Research, 40(5). 